\title{
RETHINKING SURESH: REFOULEMENT TO TORTURE UNDER CANADA'S CHARTER OF RIGHTS AND FREEDOMS
}

\author{
DAVID JENKINS*
}

This article takes the European Court of Human Rights' decision in Saadi v. Italy and uses it as an opportunity to re-examine the Canadian case of Suresh v. Canada (Minister of Citizenship and Immigration). The author argues that the national security exception in Suresh is no longer tenable in light of subsequent developments in both international and Canadian law. The author concludes that the Supreme Court of Canada should reject the Suresh exception at its first opportunity and adopt an approach to review of refoulement cases similar to that under the United Nations Convention against Torture and Other Cruel, Inhuman or Degrading Treatment or Punishment and the European Convention for the Protection of Human Rights and Fundamental Freedoms.
Cet article utilise la décision de la Cour européenne des droits de l'homme Saadi c. Italie pour réexaminer la cause canadienne Suresh c. Canada (ministre de la Citoyenneté et Immigration). L'auteur fait valoir que l'exception au titre de la sécurité nationale dans Suresh n'est plus valide à la lumière des développements subséquents autant dans le droit international que le droit canadien. L'auteur conclut que la Cour suprême du Canada devrait rejeter dès que possible l'exception de Suresh et adopter une démarche visant à réexaminer les causes de refoulement similaires en vertu de la Convention contre la torture et autres peines ou traitements cruels, inhumains ou dégradants des Nations-Unies et la Convention de sauvegarde des Droits de l'homme et des Libertés fondamentales.

\section{TABLE OF CONTENTS}

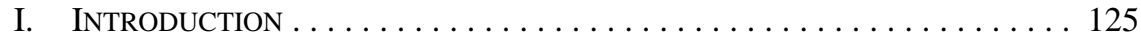

II. PRECEDENT for Torture? . . . . . . . . . . . . . . . . . . . . . . . . . 128

A. The SURESH Decision . . . . . . . . . . . . . . . . . . . . . . . . . 128

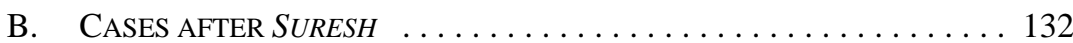

C. EVolving Standards of Fundamental Justice $\ldots \ldots \ldots \ldots 136$

III. THE NON-REFOULEMENT PRINCIPLE

AND “EXTRAORDINARY RENDITION” . . . . . . . . . . . . . . . . . . . . . 144

A. INTERNATIONAL REJECTION OF A

NATIONAL SECURITY EXCEPTION .................... 144

B. INTERNATIONAL CONDEMNATION

OF "EXTRAORDINARY RENDITION” . . . . . . . . . . . . . . . . 151

C. RENDITION AND THE "CANADIAN CONSCIENCE” . . . . . . . . . . . . 154

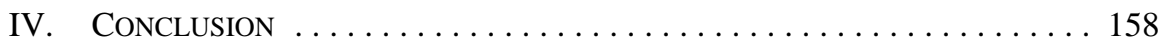

\section{INTRODUCTION}

The European Court of Human Rights (Eur. Ct. H.R.), in the case of Saadi, ${ }^{1}$ recently addressed the question of whether refoulement of an individual alleged to be a national security risk was permissible under the European Convention for the Protection of Human

Assistant Professor of Law, University of Copenhagen, Centre for European Constitutionalization, Copenhagen. The author was formerly a Lecturer in Law at the University of Aberdeen, Scotland and would like to thank the Law School for its support during the writing of this article.

Saadi v. Italy, (2008), 49 E.H.R.R. 30 [Saadi]. For a brief review of the case history, see European Court of Human Rights, Press Release, 495, “Grand Chamber Hearing Saadi v. Italy” (11 July 2007), online: International Commission of Jurists <http://www.icj.org/IMG/ECHR_Saadi_vs_Italy.pdf>. 
Rights and Fundamental Freedoms ${ }^{2}$ when he faced a serious risk of torture in the receiving country. At issue was the scope of protection under art. 3, providing that "[n]o one shall be subjected to torture or to inhuman or degrading treatment or punishment.”3 In 2005, Italian authorities arrested Nassim Saadi, a Tunisian, who was later convicted on terrorism-related charges. At about the same time, a military court in Tunisia also convicted Saadi in absentia for terrorist offenses. Soon after Saadi’s Italian conviction, the authorities sought to deport him back to Tunisia against his claim that he would be tortured upon return. Although the Tunisians offered assurances not to abuse him, Saadi brought an application before the Eur. Ct. H.R. arguing that his deportation was impermissible based on the ruling in Chahal, ${ }^{4}$ where the Court found that art. 3 absolutely prohibited the expulsion of a foreigner where there was a serious risk of torture by a third country. In the oral hearing of Saadi, the Court permitted the government of the United Kingdom to intervene as a third party and present arguments it had previously submitted in writing in another case awaiting hearing, Ramzy. ${ }^{5}$

Ramzy presented the same question as Saadi: whether art. 3 of the E.C.H.R. prohibited the applicant's return to a risk of torture. In 2002, Dutch police arrested Mohammed Ramzy, an Algerian national, on suspicion of involvement in terrorism. Although he was acquitted, Dutch immigration authorities sought to deport him as a national security risk. After Ramzy's asylum application was denied, he brought his case before the Eur. Ct. H.R., arguing that his deportation to Algeria would violate art. 3 of the E.C.H.R., per Chahal, due to a risk of torture upon return. The Eur. Ct. H.R. had already accepted party and intervening submissions in Ramzy, but had not yet heard the arguments by the time Saadi was ready for hearing.

In both Saadi and Ramzy, the U.K. argued that the Court should overturn Chahal and permit Council of Europe member states to balance the risk of torture to the individual against national security considerations. In exceptional circumstances, the U.K. submitted, those security concerns could outweigh a serious risk that an individual might be tortured by authorities in the receiving third country. ${ }^{6}$ However, in Saadi, the Eur. Ct. H.R. unanimously reaffirmed Chahal and art. 3's absolute prohibition on refoulement to torture, thereby categorically rejecting British arguments for a balancing test.

\section{November 1950, 213 U.N.T.S. 221 [E.C.H.R.].}

Ibid., art. 3.

Chahal v. United Kingdom (1996), 22 E.C.H.R. (Ser. A) 831 [Chahal] (discussed at Part III.A, below). Ramzy v. The Netherlands, No. 25424/05 (dec.) (24 May 2005) [Ramzy]. For a brief review of the case history, see European Court of Human Rights (Eur. Ct. H.R.), Press Release, 554, “Application Lodged with the Court, Ramzy v. The Netherlands” (20 October 2005), online: Eur. Ct. H.R. <http://www.echr.coe.int/Eng/Press/2005/Oct/Application/octgedRamzyvNetherlands.htm>. Lithuania, Portugal, and Slovakia intervened along with the U.K.: see Ramzy v. The Netherlands, no. 25424/05 (Observations of the Governments of Lithuania, Portugal, Slovakia and the United Kingdom) (21 November 2005). The U.K. made another such intervention in the case of $A$. v. The Netherlands, no. 4900/06 (2 February 2006).

$6 \quad$ For a summary of the British government's arguments and criticisms of Chahal, see Anthony Lester \& Kate Beattie, "Risking Torture” (2005) 6 Eur. H.R.L. Rev. 565; Rebekah Braswell, "Protection Against Torture in Western Security Frameworks: The Erosion of Non-Refoulement in the UK-Libya MOU,” Refugee Studies Centre Working Paper No. 35 (October 2006) at 18-19, online: University of Oxford <http://www.rsc.ox.ac.uk/PDFs/WP35\%20Protection\%20 Against\%20Torture\%20RB.pdf $>$. The U.K. Parliament's Joint Committee on Human Rights, however, has criticized government arguments in Ramzy and has expressed support for the decision of Chahal: U.K., Joint Committee on Human Rights, Nineteenth Report (2005-06) at paras. 21-27, online: U.K. Parliament <http://www. publications.parliament.uk/pa/jt200506/jtselect/jtrights/185/18504.htm>. 
Despite arising under the E.C.H.R., the Saadi and Ramzy cases should concern Canadians. This is because, in those two cases, Canadian law was an example for British arguments to restrict the fundamental human right not to be tortured or returned to torture, as encapsulated in art. 3 of the E.C.H.R. The British arguments were very similar to the balancing test articulated in the Canadian case of Suresh, ${ }^{7}$ in which the Supreme Court of Canada found that the Canadian Charter of Rights and Freedoms ${ }^{8}$ would likely permit deportation to torture in exceptional circumstances of danger to national security, such as where there was a threat of terrorism. The "Suresh exception," although not yet successfully invoked by the Canadian government, ${ }^{9}$ is therefore no longer just of interest to Canadian lawyers. As Saadi and Chahal suggested, despite being decided under the E.C.H.R., a Suresh-style balancing test and its national security exception are incompatible with the international peremptory norm against torture and the concomitant protective principle of non-refoulement where a torture risk exists. ${ }^{10}$ Thus, Suresh tarnishes the international reputation of Canadian law as a progressive rather than obstructive force in human rights protection and sets a bad example to other governments seeking to undermine the principle of non-refoulement. ${ }^{11}$

This article takes the Saadi decision by the Eur. Ct. H.R. as an opportunity to re-examine Suresh and argues that its national security exception is no longer tenable in light of subsequent developments in both Canadian and international law. The article assesses "fundamental justice" under s. 7 of the Charter ${ }^{12}$ with regard to Canadian cases on extradition to face capital punishment, recent criticisms of refoulement to torture by international bodies, and international condemnations of the practice of "extraordinary rendition.” Based upon the Supreme Court's s. 7 analysis in Suresh itself, this article argues that to return an individual to a serious risk of torture would always shock the conscience of Canadians (and therefore violate fundamental justice) to such a degree that it could not, under any circumstances, be justified under s. 1 of the Charter. ${ }^{13}$

Part II of the article reviews the Suresh decision and its impact on subsequent Canadian cases of refoulement to torture, as well as its similarities to the U.K.'s balancing argument rejected by the Court in Saadi. It examines how the reasoning in Suresh and other Canadian

Suresh v. Canada (Minister of Citizenship and Immigration), 2002 SCC 1, [2002] 1 S.C.R. 3 [Suresh] (discussed at Part II.A, below). Part I of the Constitution Act, 1982, being Schedule B to the Canada Act 1982 (U.K.), 1982, c. 11 [Charter].

$9 \quad$ See Part II.B, below for a review of cases where the exception was potentially an issue.

10 See Rene Bruin \& Kees Wouters, "Terrorism and the Non-Derogability of Non-Refoulement" (2003) 15 Int'l. J. Refugee L. 5 at 24-26.

11 See Louise Arbour \& Fannie Lafontaine, "Beyond Self-Congratulation: The Charter at 25 in an International Perspective" (2007) 45 Osgoode Hall L.J. 239 at 262 ("Without meaningful implementation of international norms at home, Canada impairs its credibility as an advocate of the expansion of international human rights standards abroad").

12 Charter, supra note 8, s. 7 ("Everyone has the right to life, liberty and security of the person and the right not to be deprived thereof except in accordance with the principles of fundamental justice").

Ibid., s. 1 ("The Canadian Charter of Rights and Freedoms guarantees the rights and freedoms set out in it subject only to such reasonable limits prescribed by law as can be demonstrably justified in a free and democratic society”). However, as Kent Roach points out, Parliament could still override such an absolutist decision by the Supreme Court under the "notwithstanding" clause, s. 33(1) of the Charter: Kent Roach, "Constitutional, Remedial, and International Dialogues About Rights: The Canadian Experience” (2005) 40 Tex. Int'l. L.J. 537 at 572-73 [Roach, "Dialogues about Rights”]. That section provides that "Parliament or the legislature of a province may expressly declare in an Act of Parliament or of the legislature, as the case may be, that the Act or a provision thereof shall operate notwithstanding a provision in section 2 or sections 7 to 15 of this Charter." This article, however, will not address the propriety of Parliament's hypothetical invocation of s. 33 in the event of a judicial rejection of the Suresh exception. 
decisions on extradition to face capital punishment conceives of fundamental justice as an evolutive concept, such that the Charter can accommodate, over time, more restrictive attitudes about the return to torture. Part III then considers how the non-refoulement principle and the practice of "extraordinary rendition" should impact the interpretation of ss.7 and 1 of the Charter. The peremptory norm against torture, opinions of the United Nations Committee against Torture (U.N.C.A.T.) and the Human Rights Committee (U.N.H.R.C.), and decisions of the Eur. Ct. H.R. all support an interpretation of the Charter that absolutely bars a return to torture. Furthermore, extraordinary rendition shows why the principle of nonrefoulement must be absolute, and the intensely negative reaction to Canadian complicity in the practice reveals that return to torture shocks the Canadian conscience to a degree no longer admitting of exception. This article consequently concludes that the Supreme Court of Canada should reject the Suresh exception at the first opportunity, find that the Charter unreservedly incorporates the principle of non-refoulement, and adopt an approach to review of refoulement cases similar to that of the U.N.C.A.T. and the Eur. Ct. H.R.

\section{PRECEDENT FOR TORTURE?}

\section{A. THE SURESH DECISION}

The Canadian Immigration and Refugee Board recognized Manickavasagam Suresh, a Sri Lankan, as a refugee in $1991 .^{14}$ He subsequently applied for landed immigrant status. However, in 1995, the Solicitor General of Canada and the Minister of Citizenship and Immigration issued a security certificate under s. 40.1 of the Immigration Act, ${ }^{15}$ alleging that Suresh was a member of a Tamil terrorist group and was therefore a threat to national security. Canadian authorities detained Suresh and the Minister ordered him deported under the Immigration Act as a danger to the security of Canada, due to his alleged terrorist links. ${ }^{16}$ Suresh challenged this order in the Federal Court, ${ }^{17}$ arguing that he faced a risk of torture if returned to Sri Lanka. The Court upheld the order, as did the Court of Appeal. ${ }^{18}$

On appeal to the Supreme Court, ${ }^{19}$ Suresh argued that (1) the deportation proceedings were constitutionally defective as he was denied an adequate opportunity to respond to the Government's factual determinations, (2) the Immigration Act's terms "danger to the security of Canada” and "terrorism” were unconstitutionally vague criteria for deportation, ${ }^{20}$ and (3) his deportation for his alleged political associations violated his rights to expression and

For a review of the Suresh decision, see Stephane Bourgon, "The Impact of Terrorism on the Principle of 'Non-Refoulement' of Refugees: The Suresh Case before the Supreme Court of Canada” (2003) 1 Journal of International Criminal Justice 169.

15 R.S.C. 1985, c. I-2. The Immigration Act was later replaced by the Immigration and Refugee Protection Act, S.C. 2001, c. 27 [I.R.P.A.], the security certificate and detentions provisions of which were found to be constitutionally defective under the Charter in Charkaoui v. Canada (Minister of Citizenship and Immigration), 2007 SCC 9, [2007] 1 S.C.R. 350 [Charkaoui].

Immigration Act, ibid., s. 53(1)(b).

Suresh v. Canada (Minister of Citizenship and Immigration) (1999), 173 F.T.R. 1.

For the Federal Court of Appeal decision, see [2000] 2 F.C. 592 (C.A.) [Suresh, C.A.]. For a critical review of it, see Evan Fox-Decent, "Suresh and Canada's Obligations Regarding Torture" (2001) 12 N.J.C.L. 425.

19 Supra note 7.

20 Immigration Act, supra note 15, ss. 19(1)(e)(iv)(C), (f)(ii), (f)(iii)(B), 53(1)(b). 
association under s. 2 of the Charter. ${ }^{21}$ He also argued that courts should apply a high standard of review, rather than a deferential one, to the government's factual determinations as to both an individual's security threat and his risk of torture upon return to a third country. The core of Suresh's challenge, however, was that deportation to a risk of torture, under s. 53(1)(b) of the Immigration Act, ${ }^{22}$ would violate the principles of fundamental justice under s. 7 of the Charter.

While alternatively finding for Suresh on procedural grounds, the Supreme Court's opinion on the s. 7 claim is arguably the most significant part of the decision. ${ }^{23}$ The Court pointed out that s. 53 of the Immigration Act permitted deportation in some cases even when an individual's life or freedom was threatened upon return. Of course, this statutory provision still had to comply with the Charter. ${ }^{24}$ The Court noted that the constitutional approach to resolution of the conflicting individual and public interests at stake must not only be a contextual one, but "essentially one of balancing." " 5 The Court thus began from the premise that the Charter permitted a balancing of the competing interests in Suresh's case: "Deportation to torture, for example, requires us to consider a variety of factors, including the circumstances or conditions of the potential deportee, the danger that the deportee presents to Canadians or the country's security, and the threat of terrorism to Canada." 26 Although that balance might weigh in favour of the individual in most cases, the Court hedged that "[i]t would be impossible to say in advance, however, that the balance will necessarily be struck the same way in every case.”27 The Court thus invoked a balancing test at the very outset of its s. 7 analysis, therefore seeming to reject the absolute prohibition on return to torture as argued by Suresh. Nevertheless, the Court was not prepared to give a free hand to the government. While admitting that Canada had a "legitimate and compelling interest in combatting terrorism," it also recognized that "some responses are so extreme that they are per se disproportionate to any legitimate government interest.”28 The Court had to

21 Charter, supra note 8, s. 2 ("Everyone has the following fundamental freedoms: (a) freedom of conscience and religion; (b) freedom of thought, belief, opinion and expression, including freedom of the press and other media of communication; (c) freedom of peaceful assembly; and (d) freedom of association”).

22 Immigration Act, supra note 15, s. 53(1)(b), generally prohibited deportation to a country "where the person's life or freedom would be threatened for reasons of race, religion, nationality, membership in a particular social group or political opinion," with an exception for those persons otherwise inadmissible on such grounds as involvement in terrorism under s. 19(1).

23 Suresh, supra note 7. As for Suresh's other claims, the Supreme Court found that the terms “danger to the security of Canada" and "terrorism” were not unconstitutionally vague. It also found that s. 2 of the Charter did not "protect expressive or associational activities that constitute violence" (at para. 107), while noting that s. 1 permitted the restriction of other forms of expression or association, such as hate speech or threats of violence (see R. v. Keegstra, [1990] 3 S.C.R. 697 [Keegstra]). The Supreme Court did not believe that an oral hearing was required for the immigration determination, which could be made on the record. However, it did find that the government must give Suresh access to the material on which his deportation decision was based, as well as give him an opportunity to respond to that material in writing and so challenge the government's allegations and findings of fact. According to the Court, courts should also afford deference to the government's factual decisions in deportation cases, both as to whether an individual "constitutes a danger to the security of Canada" or is involved in terrorism under ss. 9 and 53 of the Immigration Act, as well as to whether there exists a risk of torture upon return (at paras. 29-41).

Suresh, ibid. at paras. 43-44.

Ibid. at para. 45 .

Ibid. at paras. 50, 68. The Supreme Court defined torture by reference to the Convention against Torture and Other Cruel, Inhuman or Degrading Treatmeant or Punishment, 10 December 1984, 1465 U.N.T.S. 85, art. 1 [C.A.T.] and the Criminal Code, R.S.C. 1985, c. C-46, s. 269.1. The Eur. Ct. H.R. has, similarly, interpreted art. 3 of the E.C.H.R. consistently with the C.A.T. See Part III.A, below.

$27 \quad$ Suresh, ibid. at para. 45.

28 Ibid. at para. 47, citing United States v. Burns, 2001 SCC 7, [2001] 1 S.C.R. 283 [Burns] (discussed at Part II.C, below). 
determine not only whether deportation to torture would "shoc[k] the Canadian conscience" under ordinary circumstances and so violate fundamental justice, ${ }^{29}$ but also whether it would do so in all cases without exception - thereby making it a per se disproportionate response. ${ }^{30}$

The Court had little difficulty in finding that torture itself was abhorrent to Canadians in light of its absolute prohibition within the Canadian justice system. It noted that Canadian statutes and s. 12 of the Charter forbade torture, coerced confessions were inadmissible as evidence, and the death penalty had been abolished. However, deportation to face a risk of torture in another country raised issues of whether Canada bears responsibility for that torture, and whether ss. 7 and 1 would always forbid such an indirect government role in extraterritorial human rights abuses. The Court found that there was indeed a Canadian consensus against deportation to torture and so, according to this "Canadian perspective,"31 it believed that to deport an individual to a risk of torture, even out of security concerns, would normally shock the Canadian conscience. Based on Burns ${ }^{32}$ (regarding extradition to face the death penalty in the U.S.), the Government could then be responsible under the Charter for indirectly causing human rights abuses abroad. Accordingly, "[a]t least where Canada's participation is a necessary precondition for the deprivation [of s. 7 rights] and where the deprivation is an entirely foreseeable consequence of Canada's participation, the government does not avoid the guarantee of fundamental justice merely because the deprivation in question would be effected by someone else's hand."33

In defining the requirements of fundamental justice and any possible s. 1 limits, the Court looked to international law as evidence of guiding (but not controlling) principles. ${ }^{34}$ The Supreme Court declared that the prohibition against torture was a peremptory norm of international law. ${ }^{35}$ This, according to the Supreme Court, "is the norm which best informs the content of the principles of fundamental justice under s. 7 of the Charter." ${ }^{\text {" }}$ As for refoulement to torture, the Court noted that although the language of art. 33 of the Convention Relating to the Status of Refugees ${ }^{37}$ exempted national security cases from its general prohibition against a return to torture, CCPR General Comment No. 20 to art. 7 of

Suresh, ibid. at para. 49, citing Burns, ibid. at para. 60; Kindler v. Canada (Minister of Justice), [1991] 2 S.C.R. 779 at 852 [Kindler].

30 The Supreme Court, however, was unclear as to whether exceptional circumstances pled in justification of refoulement would be considered under a s. 7 or s. 1 analysis: Suresh, ibid. at para. 78, and also Part II.B, below. To determine whether a limitation on a Charter right is "demonstrably justifiable in a free and democratic society" under s. 1, a court will apply the test set out in R.v. Oakes, [1986] 1 S.C.R. 103 [Oakes]: the government objective must be substantial and pressing, the limitation must be rationally connected to that objective, the limitation must minimally impair the Charter right in question, and the infringement on that right must be proportional in light of the objective to be achieved. The deleterious and salutary effects of the limitation must also be proportional: Dagenais v. Canadian Broadcasting Corp., [1994] 3 S.C.R. 835.

Suresh, ibid. at para. 49.

Burns, supra note 28.

Suresh, supra note 7 at paras. 54, 56-57, citing Canada v. Schmidt, [1987] 1 S.C.R. 500 [Schmidt]; Kindler, supra note 29.

Suresh, ibid. at paras. 59-60.

Suresh, ibid. at paras. $62-64$ (the Court listed "three compelling indicia" to this conclusion, consisting of multilateral instruments prohibiting torture, domestic practices around the world, and international authorities).

Ibid. at para. 75 .

28 July 1951, 189 U.N.T.S. 150 [Refugee Convention]. 
the International Covenant on Civil and Political Rights ${ }^{38}$ and, especially, the Convention against Torture and Other Cruel, Inhuman or Degrading Treatment or Punishment ${ }^{39}$ reflected the "prevailing international norm," ${ }^{40}$ which rejected return to torture even when national security was at stake.

The Supreme Court found that deportation to torture would violate fundamental justice under s. 7, but with an important qualification. Falling back upon the balancing test earlier proposed, the Court believed that the $\mathrm{s} .7$ prohibition against refoulement was only a general rather than an absolute rule. ${ }^{41}$ It made a national security exception for extraordinary but undefined circumstances that might arise in the future: "We do not exclude the possibility that in exceptional circumstances, deportation to face torture might be justified, either as a consequence of the balancing process mandated by s. 7 of the Charter or under s. 1." ${ }^{\text {"42 }}$ Although apparently rare in occurrence, just what these circumstances might be was unclear. Rather, "as the matter is one of balance, precise prediction is elusive. The ambit of an exceptional discretion to deport to torture, if any, must await future cases." ${ }^{43}$ Furthermore, the Court was unclear in separating out the s. 7 and s. 1 analyses involved. ${ }^{44}$ It would not rule that refoulement to torture would be per se disproportionate under either s. 7 or s. $1 .^{45}$ Thus, the Court spent little time in explaining why, if a return to torture would shock the Canadian conscience, it could nevertheless be permitted in some exceptional circumstances. The justifications for an exception to the otherwise general prohibition under s. 7 were left unsatisfactorily explained, especially given that the Court also (and somewhat contradictorily) found that Canadian attitudes reflected international ones supporting an absolute non-refoulement principle. ${ }^{46}$ In this way, the Supreme Court came across as ambivalent about refoulement to torture and avoided conclusive statements about the exceptional case. ${ }^{47}$

16 December 1966, 999 U.N.T.S. 171 [I.C.C.P.R.]; CCPR General Comment No. 20: Article 7 (Prohibition of Torture, or Other Cruel, Inhuman or Degrading Treatment or Punishment), 44th Sess. (1996) [General Comment 20]. For more discussion of the main international sources, see Part III.A, below.

C.A.T., supra note 26 .

Suresh, supra note 7 at para. 72.

Suresh, ibid. at paras. 58, 76.

Ibid. at para. 78 .

Ibid. [emphasis added]. The Supreme Court applied the analytical framework of Suresh in the companion case of Ahani v. Canada (Minister of Citizenship and Immigration), 2002 SCC 2, [2002] 1 S.C.R. 72 [Ahani], where the appellant argued that his return to Iran on national security grounds would subject him to a substantial risk of torture. The Court found that the Minister in that case had afforded the appellant adequate procedural opportunities to challenge the deportation decision, that considerable deference should be shown to the Minister's factual assessment that a risk did not exist, and that the appellant had not "cleared the evidentiary threshold required to access the s. 7 protection guaranteed by the Canadian Charter of Rights and Freedoms" by demonstrating a serious risk of torture (at paras. 2, 17). Compare with Ahani v. Canada, U.N.H.R.C. No. 1051/2002, 80th Sess., UN Doc. CCPR/C/80/D1051/2002 (2004) [Ahani, U.N.H.R.C.], discussed at Part III.A, below. See Kent Roach, September 11: Consequences for Canada (Montreal: McGill-Queen's University Press, 2003) at 104 [Roach, September 11].

Suresh, ibid. See Bourgon, supra note 14 at 176.

Suresh, ibid. See Oakes, supra note 30.

See Kent Roach, "Must We Trade Rights for Security? The Choice Between Smart, Harsh, or Proportionate Security Strategies in Canada and Britain” (2006) 27 Cardozo L. Rev. 2151 at 2193-94 [Roach, "Must We Trade"].

Obiora Chinedu Okafor \& Pius Lekwuwa Okoronkwo, "Re-configuring Non-refoulement? The Suresh Decision, 'Security Relativism,' and the International Human Rights Imperative” (2003) 15 Int'l. J. of Refugee Law 30 at 33. The authors commented on the decision: "The court displayed, yet again, its remarkable ability to manoeuvre quite effectively between ethical principle and popular politics, between a commitment to normative supremacy, and the understandable allure of pragmatic (security-related) relativism, while reducing to the barest minimum public censure of its decision-making” [footnote 
Although Suresh clearly restricts ministerial discretion to return someone to torture in most cases, it might nevertheless allow Canada to be complicit in severe human rights abuses abroad in the undefined, exceptional case. As Kent Roach has strenuously objected on several occasions, the Suresh exception is a tempting one for the Canadian government to invoke in the future and it undermines both the rule of law and the non-refoulement principle in international law. ${ }^{48}$ The latter principle stems from the peremptory norm against torture. Indeed, the Canadian government has since invoked the Suresh exception in a few deportation cases, although as of yet unsuccessfully. Decisions in these cases are conflicting and have neither settled on the scope of the exception nor precisely how courts ought to review a government claim for an exception under ss. 7 or 1 . On the other hand, these cases indicate that the Suresh exception remains open for judicial reconsideration and eventual rejection, so that Canada can fully live up to its obligations under the non-refoulement principle.

\section{B. CASES AFTER SURESH}

Worryingly, one of the earliest attempts of the Canadian government to invoke the Suresh exception did not even involve a claim of national security, showing just how any exception to the non-refoulement principle is subject to government abuse. Canadian authorities sought to deport Mostafa Dadar, a permanent resident with refugee status to Iran as a danger to the public after he severely beat his girlfriend. Dadar challenged this decision, alleging a risk of torture if returned. The Minister determined, as a factual matter, that there was no substantial risk of torture, but alternatively argued that even if this finding were mistaken, Dadar should be deported under the exception articulated in Suresh. In Dadar (Can. F.C.), ${ }^{49}$ the Federal Court judge deferred to the Minister's determination that Dadar was indeed a threat to public safety because of his criminal history thereby justifying deportation, as well as to the decision that Dadar would not be at risk of torture if returned. Therefore, because Dadar had not produced evidence that he would indeed face a serious risk of torture and thus engage possible s. 7 protection, the judge did not address the applicability of the exception under Suresh. ${ }^{50}$

omitted]. As Roach, September 11, supra note 43 at 105, writes: "Suresh is a Janus-faced decision. Its willingness to defer to executive actions that are not patently unreasonable and its willingness to contemplate that deportation to face torture might be constitutional in an exceptional case stand in tension with its bolder and anti-majoritarian declaration under the Charter that it is, as a general rule, unacceptable to deport people to face torture.”

For his strong criticisms of Suresh, see Roach, "Dialogues about Rights,” supra note 13 at 570-74, Roach, "Must We Trade,” supra note 46 at 2193-94; Kent Roach, "Did September 11 Change Everything? Struggling to Preserve Canadian Values in the Face of Terrorism” (2002) 47 McGill L.J. 893 at 925.

49 Dadar v. Canada (Minister of Citizenship and Immigration), 2004 FC 1381, 42 Imm. L.R. (3d) 260 [Dadar (Can. F.C.)].

$50 \quad$ See also Nagalingam v. Canada (Minister of Citizenship and Immigration), 2007 FC 229, [2008] 1 F.C.R. 87, where Kelen J. explained that since there was no serious risk of harm upon return, there was no need to balance the risk of torture against the public interest justifications for deportation. In another case, however, the Federal Court found that the ministerial decision that there was not a substantial risk of torture was patently unreasonable in light of the evidence adduced by the appellant (Abdulaziz AlKafage v. Canada (Minister of Citizenship and Immigration), 2007 FC 815, 63 Imm. L.R. (3d) 234 [Al -Kafage]). Contrast Al-Kafage with Krishnan v. Canada (Minister of Citizenship and Immigration), 2007 FC 846, 63 Imm. L.R. (3d) 38 at para. 27 [Krishnan], where the Federal Court made clear that post-decision changes in country condition, which might have increased the risk of harm to a deportee but had not been considered by the Minister, were unreviewable. 
Nevertheless, the Dadar (Can. F.C.) case highlights concerns that the Suresh exception might be widened beyond a truly extraordinary case of national security to include "ordinary" criminal cases. ${ }^{51}$ While Dadar's criminal history might have legally justified his deportation order, ${ }^{52}$ it was the Government's readiness to invoke the Suresh exception in the case that makes it so troubling. Dadar (Can. F.C.) evidenced a readiness to argue fast and loose with what the Supreme Court had apparently intended in Suresh to be a narrowly drawn national security exception. In another case, Al-Kafage, ${ }^{53}$ the Federal Court seemed to leave open the possibility that, should a reviewing court indeed find a serious risk of torture upon return, it might still engage in the $\mathrm{s} .7$ balancing test even where an individual is declared inadmissible on grounds of serious criminality (such as sexual assault), rather than national security. Like Dadar (Can. F.C.), Al-Kafage raises concerns that the Suresh exception could potentially be widened beyond its originally narrow and exceptional national security confines to permit deportation to torture as a consequence of “ordinary” criminal conduct.

The Canadian government has also acted in contempt of decisions by the U.N.C.A.T., ignoring its requests for interim measures and proceeding with deportations even where the U.N.C.A.T. has expressed concern with the Canadian government's and courts' torture risk assessments. For example, Canadian authorities insisted on returning Dadar to Iran, despite a finding by the U.N.C.A.T. that a serious torture risk existed. ${ }^{54}$ Similarly, in Sogi, ${ }^{55}$ the U.N.C.A.T. disagreed with Canadian risk assessments and decided that Canada had violated the C.A.T. by ignoring the U.N.C.A.T.'s interim request for a stay of deportation and instead returning the applicant to India to face what the U.N.C.A.T. found to be a serious risk of torture. The Federal Court had earlier certified Bachan Singh Sogi's case for appeal to the Federal Court of Appeal on the question of whether or not his alleged terrorist connections were so exceptional as to permit his deportation to a risk of torture, a risk that the government had already twice acknowledged. ${ }^{56}$ That case became moot, however, after the government decided that the situation in India had changed sufficiently to eliminate the torture risk and therefore allow deportation. ${ }^{57}$ The U.N.C.A.T., in its Sogi decision, found this change in the risk assessment to be flawed, resulting in a breach of the C.A.T. ${ }^{58}$ The case of Sogi shows how the Canadian government might be tempted to underestimate or downplay a risk of torture in light of pressing national security concerns, and therefore attempt to avoid the Suresh balancing test altogether.

However, a serious criminal conviction by itself is insufficient to prove an individual to be a threat to the public under the I.R.P.A. Rather, the Minister must assess the facts of each case and determine the potential for reoffending: Thuraisingam v. Canada (Minister of Citizenship and Immigration), 2004 FC 607, 40 Imm. L.R. (3d) 145; Mohamed v. Canada (Minister of Citizenship and Immigration), 2008 FC 315, 165 A.C.W.S. (3d) 890.

$53 \quad$ Al-Kafage, supra note 50.

54 Dadar v. Canada, U.N.C.A.T. No. 258/2004, 35th Sess., UN Doc. CAT/C/35/D/258/2004 (2005) [Dadar (U.N.C.A.T.)]. The Federal Court refused an order staying Dadar's deportation based upon the U.N.C.A.T. decision in this case: Dadar v. Canada (Minister of Citizenship and Immigration), 2006 FC 382, [2006] F.C.J. No. 486 (QL); see “Dadar Deported to Iran Despite Fears of Torture” CBC News (27 March 2006), online: CBC <http://www.cbc.ca/canada/new-brunswick/story/2006/03/27/nb_ dadardeported20060327.htm $>$. As discussed at Part III.A, below, the opinion of the U.N.C.A.T. was one of a series of international criticisms against a Suresh-style balancing approach to refoulement.

Sogi v. Canada, U.N.C.A.T. No. 297/2006, 39th Sess., UN Doc. CAT/C/39/D/297/2006 (2007) [Sogi].

Sogi v. Canada (Minister of Citizenship and Immigration), 2005 FC 262, [2005] 3 F.C.R. 530.

Sogi v. Canada (Minister of Citizenship and Immigration), 2007 FC 108, 160 A.C.W.S. (3d) 1043.

Sogi, supra note 55. 
The Federal Court has in other cases, to be sure, shown a reluctance to broaden the Suresh exception, but has not directly addressed the issue. For example, the government relied on the Suresh exception in Mahjoub, ${ }^{59}$ alleging that Mohamed Mahjoub's involvement with international terrorism presented a national security risk that would justify his return to a serious risk of torture in Egypt. Again, however, the Court ultimately did not address the Suresh exception. It instead found that the Minister's conclusion that Mahjoub was a danger to the security of Canada was patently unreasonable, thereby preventing deportation. ${ }^{60}$ Although avoiding the constitutional issue, the Court stated that it was unsure whether any exception was indeed permissible after all: "There are ... powerful indicia that deportation to face torture is conduct fundamentally unacceptable; conduct that shocks the Canadian conscience and therefore violates fundamental justice in a manner that cannot be justified under section 1 of the Charter." ${ }^{\text {"61 }}$ The Federal Court in Mahjoub was hesitant to address the Suresh exception in all but a clear case. Moreover, in obiter dicta, the judge in Mahjoub questioned outright the Suresh exception itself.

In Jaballah, ${ }^{62}$ the Federal Court addressed a clear case for consideration of the Suresh exception. The Court agreed with the Government that Mahmoud Jaballah presented a high security risk to Canada, due to alleged connections with Al Qaeda, and that there was a serious risk of torture upon return. The Court found, nevertheless, that the national security concerns were not weighty enough to justify return to torture. ${ }^{63}$ It emphasized the truly extraordinary nature of the Suresh exception, and recognized the countervailing principle of non-refoulement in both international and Canadian law. ${ }^{64}$ The Court not only signalled a restrictive approach to the scope of any exception, but, as in Mahjoub, took a skeptical view of whether such an exception was constitutionally acceptable in the first place.

In these and other cases since Suresh, the Federal Court has demonstrated the same ambivalence as the Supreme Court towards a return to torture, vacillating between supporting it in exceptional (or even not so exceptional) circumstances and expressing misgivings about whether such a return could ever comply with ss. 7 and 1 of the Charter. However, this inconclusive position still permits a positive outlook. The Supreme Court in Suresh, and the Federal Court in cases following it, clearly took into account international law in their analysis of fundamental justice; they recognized the peremptory norm against torture and the protective principle of non-refoulement as indicators of Canadian values. ${ }^{65}$ This leaves open

valoub vanada (Minister of Citizenship and Immigration), 2005 FC 156, [2005] 3 F.C.R. 334 [Mahjoub].

Ibid. at para. 47.

Ibid. at para. 64.

Re Jaballah, 2006 FC 1230, 58 Imm. L.R. (3d) 267 [Jaballah].

Ibid. at paras. $79-86$.

Ibid. at paras. 80-86. In Almrei v. Canada (Minister of Citizenship and Immigration), 2005 FC 1645, 50 Imm. L.R. (3d) 160 [Almrei], the Federal Court stated that "[t]he Supreme Court of Canada has not determined what circumstances could exist to justify deportation to face torture" (at para. 268). The Federal Court suggested that Suresh itself, while leaving open the question of such removal in exceptional cases, nevertheless indicated that deportation to torture might ultimately violate $\mathrm{s} .7$ in a way that could never be justifiable under s. 1. See also Mahjoub, supra note 59 at paras. 43, 64.

Certainly, s. 7 of the Charter now restrains ministerial deportation decisions far more than before Suresh. As Okafor and Okoronkwo observe, supra note 47 at 62-64, the Suresh decision and its balancing test constitutionally restricted ministerial discretion to deport individuals to a risk of torture upon grounds of national security more narrowly than just under the Immigration Act alone. Previously, Canadian immigration law had reflected the Refugee Convention, supra note 37, art. 33, which excepted from the Convention's non-refoulement requirement those cases where the individual posed much less of a risk to national security. Post-Suresh, however, ministerial discretion to deport such individuals to 
the possibility that whenever an appropriate case presents itself, a court might very well decide that a return to torture will always be a violation of fundamental justice, unjustifiable under s. 1. To borrow words from the Federal Court in Mahjoub, there are "powerful indicia" that the proposed, yet untested, Suresh exception itself is unconstitutional. ${ }^{66}$ On the negative side, of course, the possibility of an exception remains, which courts could conceivably broaden beyond the most serious national security cases.

As highlighted in the introduction, another troubling consequence of Suresh is that other countries have looked to its balancing test in arguing that a government should be allowed to deport an individual to face torture in cases where national security is threatened, a position contrary to the protective principle of non-refoulement in international law, as well as regional human rights treaties like the E.C.H.R. ${ }^{67}$ The U.K. and a few other European states have recently advocated a Suresh-style balancing test in an unsuccessful attempt to overturn the Eur. Ct. H.R. decision in Chahal. Saadi rejected that approach, but the fact that the Eur. Ct. H.R. even entertained the British arguments suggests that Suresh stands as a bad international example. Canadians often pride themselves for having a legal system that both respects human rights and stands as an example to foreign jurisdictions. ${ }^{68}$ Unfortunately, Saadi shows that other countries can now look to Canada and Suresh in an attempt to undermine, rather than better realize, human rights protection. This is not the example that Canadians should wish their legal system to set for the world, and it advertises that Canada itself is not fully living up to its obligations under international human rights law. Suresh suggests to both the Canadian government and other countries that despite the Charter, the E.C.H.R., or international law, fundamental human rights are a matter of convenience and come second to national security concerns. This message, in light of otherwise legitimate security worries, is a powerful one for security-obsessed governments and a discouraging one to human rights advocates. On calm reflection, and with the benefit of hindsight regarding the torture controversies during the so-called "war against terrorism," Canadian values surely cannot now be thought to embrace this kind of national human rights exceptionalism.

Therefore, the Eur. Ct. H.R.'s and the U.N.C.A.T.'s unequivocal rejection of a Sureshstyle exception should signal to the Supreme Court of Canada that it got the balance wrong in Suresh. International developments encourage judicial re-examination of Suresh, for the very reason the Supreme Court took such considerable account of international law in assessing the requirements of fundamental justice under s. 7 of the Charter. Accordingly, there remains good cause to rethink the Suresh exception in light of both subsequent domestic and international legal developments, in much the same way as the Supreme Court

a risk of torture is restricted by s. 7 , as understood in the light of, inter alia, the C.A.T., which overrides the exception of the Refugee Convention. From this relativistic perspective, Suresh was indeed an improvement on Canadian immigration law. From a human rights and international law perspective, however, the decision is still flawed by allowing any exception at all.

$66 \quad$ Mahjoub, supra note 59 at para. 64.

67 Okafor \& Okoronkwo, supra note 47 at 31[footnote omitted], predicted that Suresh would not only have implications in Canada, but "may also have some persuasive value in the courts of other refugeereceiving countries. In any event, this decision has extremely important implications for the way convention refugees and asylum seekers are treated not just in Canada, but the world over as well, especially in our current post-9/11 world order.” Bruin \& Wouters, supra note 10 at 8-11, point out, however, that at the same time the Supreme Court was considering the Suresh case, the European Commission was already advocating a return to a similar balancing test, contrary to the absolute prohibition on refoulement to torture in the E.C.H.R., supra note 2, art. 3, per Chahal. See Arbour \& Lafontaine, supra note 11 at 242-43, 250-51. 
re-evaluated extradition to face capital punishment in Burns. ${ }^{69}$ At the first opportunity, therefore, a court should follow up the Federal Court's obiter dicta in Mahjoub ${ }^{70}$ and find that deportation to a serious risk of torture would so shock the Canadian conscience that it could never, under any circumstances, be permissible under either s. 7 or s. 1 of the Charter.

\section{EVOLVING STANDARdS OF FUNDAMENTAL JUSTICE}

Despite the national security exception, the Court's particular analytical approach to s. 7 rights (at least in the context of an alien's expulsion) in Suresh remains sound, accommodates changes in Canadian values over time, and assumes that Canadian values are broadly in step with Canada's international human rights obligations. The Court's mistake in that case was in going too far, in obiter dicta, to balance out the relevant factors in favour of an exception to the general principle against return to torture. However, before considering how and why the Suresh factors must now be re-balanced, some brief attention should be given to the Court's later decision in Malmo-Levine, ${ }^{71}$ refining the framework for determining new principles of fundamental justice, as well as the continuing controversy over the place of international law in Charter interpretation. In Malmo-Levine, the Court rearticulated standards it had previously teased out for determining s. 7 principles:

In short, for a rule or principle to constitute a principle of fundamental justice for the purposes of s. 7, it must be a legal principle about which there is significant societal consensus that it is fundamental to the way in which the legal system ought fairly to operate, and it must be identified with sufficient precision to yield a manageable standard against which to measure deprivations of life, liberty or security of the person. ${ }^{72}$

In applying these elements, a court can consider the proposed principle's status under international law. ${ }^{73}$ Although it is beyond question that international treaties do not directly form part of Canadian law until legislatively incorporated, the proper extent of their interpretive influence and the role of customary international law are uncertain and debatable. Thus, despite the Court's regular reliance upon international law for interpreting the Charter, it has yet to establish a consistent rationale or set of constitutional guidelines for its use. ${ }^{74}$ The Supreme Court has instead long demonstrated a "flexible" or "functional" approach to how, when, and to what degree it will use international law. ${ }^{75}$ This means that "the methodological framework for international law, at present, is imperfect at best and

Supra note 28.

Supra note 59 at para. 64.

R. v. Malmo-Levine, 2003 SCC 74, [2003] 3 S.C.R. 571 [Malmo-Levine].

Ibid. at para. 113.

See Canadian Foundation for Children, Youth and the Law v. Canada (Attorney General), 2004 SCC 4 , [2004] 1 S.C.R. 76 at paras. 8-9 (when determining or applying principles of fundamental justice, the relevant context might also involve comparative law and public policy). See also Chaoulli v. Quebec (Attorney General), 2005 SCC 35, [2005] 1 S.C.R. 791 at paras. 139-50 [Chaoulli].

74 See generally Melissa A. Waters, "Creeping Monism: The Judicial Trend Toward Interpretive Incorporation of Human Rights Treaties” (2007) 107 Colum. L. Rev. 628 (arguing that interpretive judicial techniques in dualist systems can lead towards the effective incorporation of international law); Gerald P. Heckman, "International Human Rights Law Norms and Discretionary Powers: Recent Developments” (2003) 16 Can. J. Admin. L. Prac. 31 [Heckman, “International Human Rights Law Norms"] (criticizing the court's inconsistency towards the application of international human rights law in limiting executive discretionary power).

75 Lorraine E. Weinrib, “A Primer on International Law and the Canadian Charter" (2007) 21 N.J.C.L. 313 at 320. See e.g. Slaight Communications v. Davidson, [1989] 1 S.C.R. 1038; Keegstra, supra note 23; Baker v. Canada (Minister of Citizenship and Immigration), [1999] 2 S.C.R. 817 [Baker]; Charkaoui, supra note 15. 
improvised at worst."76 Accordingly, even under Malmo-Levine, the elucidation of the principles of fundamental justice will arguably incorporate some judicial subjectivity, ${ }^{77}$ at the same time that the rules for using international law in Charter interpretation and judicial review remain ill-defined and controversial.

While they are thus ripe for further scholarly commentary, in-depth discussion of either the Malmo-Levine framework or the Supreme Court's use of international law is ultimately unnecessary to this article's basic argument. First, as emphasized below, the Supreme Court has already established the principle of fundamental justice at issue in refoulement or extradition cases; reconsideration of the Suresh exception does not involve "finding" any new principle per Malmo-Levine, but rather involves tailoring an existing one. Second, in applying that principle, the Court has clearly opened the door to international law as a significant consideration in judging just what possible treatment will shock the Canadian conscience. No matter how one characterizes or theoretically justifies its use, international law can be a determinative factor in this balancing process, as already established by the Court in Suresh and other cases such as Kindler and Burns. ${ }^{78}$ For these reasons, this article is less concerned with s. 7 jurisprudence generally or with setting out a prospective, coherent theory for the use of international law in Charter interpretation than in making the point that, when it comes to what shocks the conscience in the refoulement context, the dictates of the Canadian conscience are in step with international trends. The article therefore proceeds on the narrower and less problematic premise that the Court simply got the balance of factors wrong in Suresh (whether under ss. 7 or 1) or, alternatively, that some of those contextual factors have since changed so as to shift that balance upon reweighing.

As for the principle now in issue, while it was clear to the Court in Suresh that s. 7 prohibited torture directly by Canadian officials in all circumstances, ${ }^{79}$ the possibility of a return to torture by foreign third parties was a more difficult question, at least where Canada had legitimate and compelling national security interests in expelling the individual. Nevertheless, the Court found, without difficulty, that s. 7 generally prohibited a return to torture by extending the existing principle against return to fundamentally unjust treatment outside of Canada. ${ }^{80}$ The Court thus recognized that in assessing proposed principles of fundamental justice, "[t]he approach is essentially one of balancing." ${ }^{\text {, }}$ Such principles were embedded in "the basic tenets of our legal system," and were "determined by a contextual approach" so that "the outcome may well vary from case to case depending on the mix of contextual factors put into the balance." 82 Like other cases before it then, Suresh indicated that this balancing of factors infused all levels of s. 7 analysis, from the initial articulation of the general principle against a return, to fundamentally unjust treatment abroad, to the

Arbour \& Lafontaine, supra note 11 at 252.

See Chaoulli, supra note 73 at para. 191.

Kindler, supra note 29; Burns, supra note 28.

For the fundamental nature of the torture prohibition in the common law and wider Western legal tradition, see A. v. Secretary of State for the Home Department (No. 2), [2006] 2 A.C. 221 (H.L.) (forbidding the admission of torture evidence in administrative proceedings, based on principles of common law); David Jenkins, "The European legal tradition against torture and Implementation of Article 3 of the European Convention on Human Rights” [2007] Public Law 15.

Suresh, supra note 7 at paras. 52-57. See Singh v. Minister of Employment and Immigration, [1985] 1 S.C.R. 177; Schmidt, supra note 33; Kindler, supra note 29; Burns, supra note 28.

Suresh, ibid. at para. 45.

Ibid., quoting Kindler, supra note 29 at 848; Burns, supra note 28 at para. 65. 
more contextualized (and possibly more difficult) application of that principle by way of the "shocks the conscience" test. While proposed returns to ill treatment would usually be a violation of $\mathrm{s.}$, what would shock the conscience was ultimately to be determined on a case by case basis. ${ }^{83}$ While one might argue that, on retrospective analysis, the Court's conclusion in Suresh does or does not meet the specific elements of the later Malmo-Levine framework, the fact is that the Court has already laid down the s. 7 principle involved in refoulement cases. Moreover, the Malmo-Levine criteria are not necessary for a reconsideration of the national security exception itself; that question is only an exercise in contextually applying the existing s. 7 principle through re-balancing the relevant factors in a contemporary light.

As far as that balancing exercise goes, Malmo-Levine nevertheless did make the point that ss. 7 and 1 analyses are not to be confused. The Court explained that, "despite certain similarities between the balancing of interests in ss. 7 and $1 \ldots$ the issue under s. 7 is the delineation of the boundaries of the rights and principles in question whereas under s. 1 the question is whether an infringement may be justified." ${ }^{44}$ The Supreme Court elaborated upon this point in Charkaoui, when reviewing the statutory procedures for issuing special security certificates against aliens to be detained and deported as national security threats. According to the Court there, at the s. 7 stage, "[t]he issue is whether the process is fundamentally unfair to the affected person. If so, the deprivation of life, liberty or security of the person simply does not conform to the requirements of s. 7. The inquiry then shifts to s. 1 of the Charter." 85 As has been noted, the Court in Suresh was reticent in this regard, not making clear whether the proposed national security exception would fall entirely outside of s. 7 as conduct that would not shock the conscience or instead would be a justifiable s. 1 limitation. ${ }^{86}$

However, in Malmo-Levine, the Court cited Suresh for the proposition that, during the s. 7 balancing phase, an otherwise legitimate government measure might nevertheless be a per se disproportionate response. The applicable standard set out in Malmo-Levine, to be proven by the claimant, was to be that of "gross disproportionality." ${ }^{87}$ For the reasons set out in detail in Part III of this article, return to a risk of torture would now surely be considered such a grossly disproportionate response under s. 7 in light of the irreversibility of torture, international condemnations against refoulement, and unsavoury Canadian experiences with extraordinary rendition over the last several years. However, Suresh still begs the question as to whether such an absolutist s. 7 principle could ever be justified under s. 1, due to pressing national security concerns. The strong international prohibition against balancing away the right not to be tortured, as result of a utilitarian, national security-focused calculus — the very thrust of Saadi, for example — points towards a new Canadian sensitivity to the prospect that delivering an individual into the hands of potential torturers is inherently unreasonable and unjustifiable in a free and democratic society. Furthermore, although it has

83 Suresh, ibid. at para. 45.

Malmo-Levine, supra note 71 at para. 97, citing R. v. Mills, [1999] 3 S.C.R. 668. The other difference is that the claimant must first demonstrate a violation of $s$. 7 , whereupon the burden shifts to the government to justify its infringement under s. 1 .

Charkaoui, supra note 15 at para. 22.

Suresh, supra note 7 at para. 78.

Malmo-Levine, supra note 71 at paras. 141-43 [emphasis omitted]. This standard of gross disproportionality, when applied to punishment, is the same as under s. 12, although the ambit of s. 7 is broader than any of the specifically enumerated rights in the Charter, thereby taking into account potentially adverse consequences for a claimant in a relatively wide context (at paras. 159-60, 169-70). See also Re B.C. Motor Vehicles Act, [1985] 2 S.C.R. 486 at para. 63 [B.C. Motor Vehicles]. 
not decided the issue, the Supreme Court's jurisprudence strongly indicates that a per se disproportionate response under s. 7 represents such a gross violation of fundamental justice that it cannot thereafter be saved under s. $1 .^{88}$ While the Court has left open the possibility that s. 1 might exceptionally permit a s. 7 infringement "in times of war or national emergencies," 89 it is highly doubtful that even the government's legitimate security concerns in the terrorism context would meet this threshold, in the absence of a greater, existential national threat. ${ }^{90}$ Going further, some denials of fundamental justice are potentially so extreme and irremediable in their deleterious effects on the individual — as when returning that person to a serious risk of torture in a foreign country - that they could never pass s. 1 muster even in extreme national crises. ${ }^{91}$ The Constitution offers the federal Parliament and provincial assemblies recourse in such grave circumstances, via the "notwithstanding clause," s. 33, of the Charter.

In any case, the judicial determination of just when a return to a risk of torture would shock the conscience, or otherwise be justifiable (or not) under s. 1, requires a contextual weighing of individual and government interests. This process involves more than a simple poll of Canadian opinion on where the balance should be struck, deference to government decision, or some kind of utilitarian calculus. Rather, as discussed below with reference to Kindler and Burns, the "shocks the conscience" test is a complex, value-laden calculation; international law, though not directly incorporated due to Canada's dualist system, is an important part of this judicial value judgment. In this way, the Court has recognized the evolution of s. 7 principles over time, within specific contexts, and partly based on developments in international law and world opinion. As the Court recognized in Suresh, even though international law alone is not controlling or determinative of Charter rights, it can "tip the balance in favor of a rights-conscious interpretation" to ss. 7 and $1 .^{92}$ Thus, the "inquiry into the principles of fundamental justice is informed not only by Canadian experience and jurisprudence, but also by international law, including jus cogens."93 This apparent assumption that Canadians value world opinion and honour their international obligations means that international sources are relevant at every stage of the s. 7 analysis, as well as in any subsequent s. 1 inquiry. Therefore, whatever the outstanding questions or concerns about the role of international law in Charter interpretation generally, in Suresh the Court left no doubt about its relevance and high importance in a case of refoulement. In rebalancing the factors considered by Suresh, international law is one of many elements that judges will take as indicators of Canadian values. [Heywood]; Chaoulli, supra note 73 at para. 155; Mahjoub, supra note 59 at para. 64; Almrei, supra note 64 at para. 268.

$89 \quad$ Heywood, ibid. See also B.C. Motor Vehicles, ibid. at para. 85; Suresh, supra note 7 at para. 78; New Brunswick (Minister of Health and Community Services) v. G.(J.), [1999] 3 S.C.R. 46 at paras. 95-100. Re Application under s. 83.28 of the Criminal Code, 2004 SCC 42, [2004] 2 S.C.R. 248 at para. 39. See also David Jenkins, "Human Rights and Public Emergency Discourse in the U.K. and Canada,” in Christopher P.M. Waters, ed., British and Canadian Perspectives on International Law (Leiden: Martinus Nijhoff, 2006) 187 at 187-201.

See Oakes, supra note 30 at paras. 68-71.

Waters, supra note 74 at 675 .

Suresh supra note 7 at para. 46. For a careful but encouraging look at how Canadian judges should apply international law, see generally Jutta Brunnée and Stephen J. Toope, “A Hesitant Embrace: Baker and the Application of International Law by Canadian Courts” in David Dyzenhaus, ed., The Unity of Public Law (Portland: Hart, 2004) 357. 
To summarize, the Malmo-Levine framework, and the Court's uncertain approach to international law generally, do not impact the re-balancing of the factors behind the Suresh exception. First, the Malmo-Levine framework would not apply in reviewing the Suresh exception, for the very reason that the Court would not be searching for a new principle of fundamental justice. Rather, an established s. 7 principle already forbids expulsion of an individual to face treatment abroad that would shock the conscience of Canadians; it is at the stage of applying this s. 7 principle where the balancing is to be done between an individual's interest in not being returned to torture and the government's interest in protecting national security. Second, while the Supreme Court has not yet conclusively ruled that violations of s. 7 can never be justified under s. 1 (the Court in Suresh was itself undecided in differentiating s. 7 from s. 1 balancing, perhaps in order to avoid committing itself on this point), obiter dicta in other cases strongly suggest that some s. 7 violations will always be per se unjustifiable in a free and democratic society. This would mean that an expulsion to face treatment that shocks the conscience cannot then be saved by s. 1, even during national emergencies. Third, Canadian and not foreign experiences and values are ultimately determinative of the principles of fundamental justice (including what shocks the conscience) and the Charter does not directly incorporate international law. However, there is apparently a strong assumption by the Supreme Court that Canadians value international law and, for that reason, it will interpret s. 7 so as to "harmonize" the basic tenets of Canada's legal system with its international human rights obligations. Finally, this approach to s. 7, as well as to s. 1, must therefore not only have regard to the particular context of each case, but also accommodate evolving social and legal standards from a cosmopolitan, rather than parochial, perspective. In so far as these standards will change over time domestically or internationally, so too will the requirements of fundamental justice. In reweighing the factors involved in ss. 7 and 1 balancing, both domestic and international events are bellwethers to the Court.

The pre-Suresh decisions in Kindler $^{94}$ and Burns, ${ }^{95}$ dealing with extradition to face capital punishment abroad, illustrated early on this cosmopolitan and evolutive approach to discerning principles of fundamental justice. It is in those decisions, rather than in the Malmo-Levine framework for new s. 7 principles or the broader debates about the use of international law, that one finds the indicators for how a judge ought to re-balance the factors involved in the Suresh exception. These cases show how established principles of fundamental justice can quickly develop over a relatively short time period to impose increasingly stringent constitutional protections for human rights, particularly in the context of what will shock the conscience with regard to expulsions. Kindler, decided in 1991, ${ }^{96}$ concerned an American fugitive who had been convicted of first-degree capital murder (among other offences) in the U.S., but had escaped from prison to Canada before sentencing. Upon capture in Canada, the Minister of Justice arranged for his extradition pursuant to a treaty with the U.S., but refused to seek diplomatic assurances that Kindler would not be sentenced to death. Kindler argued that his extradition to face the death penalty would violate s. 7 guarantees of fundamental justice, as well as the s. 12 prohibition on cruel

Kindler was decided along with the companion case Reference Re $\mathrm{Ng}$ Extradition (Can.), [1991] 2 S.C.R. 858 . 
and unusual treatment or punishment. ${ }^{97}$ In evaluating whether Kindler's return would comply with the requirements of fundamental justice under s. 7, the Court had to decide whether extradition to face the death penalty would "shock the conscience" of Canadians. ${ }^{98}$ In so deciding, according to the Court, "the question is whether the provision or action in question offends the Canadian sense of what is fair, right and just, bearing in mind the nature of the offence and the penalty, the foreign justice system and considerations of comity and security, and according due latitude to the Minister to balance the conflicting considerations." ${ }^{99}$ The Court could also have reference to such indicators as domestic legal principles, public opinion statistics, and international practice. ${ }^{100}$ Furthermore, although most Justices, both in the majority and dissent, found that a s. 12 analysis was not appropriate to the case at bar, as the threatened actions would occur outside Canada, they believed that the underlying principles of that analysis could nonetheless inform the interpretation of s. $7 .^{101}$ Even so, the majority of the Court found that extradition without assurances would not violate s. 7. The judges considered several contextual factors in coming to this conclusion. For example, extradition was imperative for particularly serious violent crimes, the Canadian public seemed to be divided on the question of capital punishment (despite its then abolition in Canada except for certain military crimes), and there was no clear international proscription against the death penalty (again, despite a significant trend towards its abolition). In addition to these factors, the American criminal justice system provided extensive due process guarantees to an accused and there was a compelling public interest that Canada should not become an international haven for fugitives accused of serious crimes. ${ }^{102}$ Taking all this into consideration, the Court believed that to return the appellant to the U.S. without assurances would not shock the conscience of Canadians and therefore would not violate the principles of fundamental justice under s. 7.

In contrast, the short dissenting opinion of Sopinka J. (with Lamer C.J.C.) balanced out similar factors in the other direction. Sopinka J. opined in obiter dicta that capital punishment per se violated s. 12, but preferred to decide the issue under $\mathrm{s} .7$ because the death penalty might be imposed by a foreign government instead of Canada. ${ }^{103}$ However, he was of the view that s. 7 protection rested upon principles reaching beyond a determination of what might "shock the conscience" of Canadians, in the sense of an opinion poll, in order to protect against "unjust situations which are not recognized as such by the majority." 104 Furthermore, Sopinka J. called attention to the fact that this was not a situation in which the appellant would escape justice altogether if not returned to the U.S.; he could still receive life imprisonment. The Minister's refusal even to request assurances was consequently disproportionate, as extradition with assurances would equally serve to achieve Canada's legitimate and compelling interests in extradition. Otherwise, "[t]o refuse to seek such assurances is to give an official blessing to the death penalty, despite the fact that Canadian

Charter, supra note 8, s. 12 ("Everyone has the right not to be subjected to any cruel and unusual treatment or punishment”).

Kindler, supra note 29 at 832, 849, citing Schmidt, supra note 33.

Kindler, ibid. at 850.

Ibid. at 832-34.

Ibid. at 790-92, 831, 847. Chief Justice Lamer and Cory J. dissented on this point, finding that s. 12 of the Charter did apply to extradition proceedings.

Ibid. at 834-36, 853, 855-56.

Ibid. at 790-92 (compare with Cory J. at 818-24, 827, finding that s. 12 did apply to prevent extradition). Ibid. at 791 . 
public policy stands firmly opposed to its use.” ${ }^{105}$ Furthermore, with regard to the possibility of a justifiable infringement of Kindler's Charter rights, "[t]he situations in which a breach of s. 7 can be justified under s. 1 will be exceedingly rare.” ${ }^{106}$ Sopinka J. tersely denied that the case at hand was such an exceptional one.

Kindler showed that the s. 7 balancing test did not lead to a static result, but rather one dependent upon a variety of contextual factors and legal principles. Indeed, in just a decade, the Supreme Court would change its holding, in Burns, and find that extradition without assurances against the death penalty would violate s. 7. Sebastian Burns and Atif Rafay, both Canadian citizens, were wanted for the savage murders of Rafay's parents and sister in Washington state. After the pair fled the U.S., Canadian authorities arrested them in British Columbia and the Minister of Justice subsequently initiated proceedings to extradite them to the U.S. without seeking assurances against imposition of the death penalty. In a unanimous decision, the Supreme Court found that such a return would violate s. 7 in all but exceptional cases, overturning its previous decision in Kindler. ${ }^{107}$ Interestingly, however, the Court applied the same analytical framework as it had in the prior case, essentially only rebalancing the relevant factors. ${ }^{108}$ Although the Court repeated its position in Kindler that it should give deference to the Minister's extradition decisions, it undertook a fresh reexamination of the issue by recognizing that the permanence of capital punishment and the dangers of mistaken convictions "open ... up a different dimension." 109 That the Court was willing to take a new look was clear. It emphasized that the s. 7 balancing approach was context dependent and then appeared to adopt the position of Lamer C.J.C. in Kindler that the shocks the conscience standard for $\mathrm{s} .7$ should not be narrowly construed as a litmus test of popular opinion. It was instead anchored on legal principles, a fair justice system, and a mandate to protect "the worst and weakest" against majoritarian excesses. ${ }^{110}$ Thus, within this richer, value-laden context, what would violate fundamental justice would, equally, always shock the conscience of Canadians. Such a standard signified treatment "so extreme that it becomes the controlling issue ... and overwhelms the rest of the analysis," 111 irrespective of other countervailing state interests. The death penalty, controversial as it had become within the previous decade both domestically and internationally, and in light of new concerns about unsafe convictions, had become such a controlling issue for the Court in Burns. ${ }^{112}$

Ibid. at 792-93.

Ibid. at 793.

As in Kindler, the Court again declined to consider the extradition issue under s. 12 because the imposition of capital punishment would itself be at the hands of a foreign state, notwithstanding Canada's role in the causation. Nevertheless, it repeated that s. 12 was a relevant consideration in the s. 7 balancing process. The Court also rejected an argument that extradition would violate s. 6 mobility rights: Burns, supra note 28 at paras. 54-57.

Burns, ibid. at para. 129 (as the Court noted, “[t]he 'balancing process' mandated by Kindler and $\mathrm{Ng}$ remains a flexible instrument").

Ibid. at para. 38.

Ibid. at paras. 64-71, citing S. v. Makwanyane (1995), 6 B. Const. L.R. 665 at para 88.

Burns, ibid. at para. 69.

Mark Warren, "Bordering on Discord: The Impact of the Death Penalty on U.S.-Canada Relations" (2006) 6 Journal of the Institute of Justice \& International Studies 79 at 87 ("A range of new considerations had tipped the scales, just ten years on”). As Roach in Roach, "Dialogues about Rights," supra note 13 at 567, writes: "In many ways, Burns shows dialogic judicial review at its very best. The Court was sensitive to emerging trends and not overly concerned with whether they constituted official norms of international law or were binding in domestic law. It was willing to use all of this information to engage in critical self-reflection and effectively reverse decisions it had made only a decade earlier." For more discussion of the use of international law by Canadian courts, and the concept of inter-branch and international legal dialogue, see René Provost, “Judging in Splendid Isolation,” (2008) 56 Am. J. Comp. L. 125. According to Michel Coutu \& Marie-Hélène Giroux, "The Aftermath of 11 September 
Again, as in Kindler, Canadian as well as international views were relevant considerations for the Supreme Court. The Court had little trouble in finding that, for Canadians, "capital punishment is unjust and it should be stopped."113 Although refusing to decide whether capital punishment per se violated s. 12, as suggested by Sopinka and Cory JJ. in Kindler, the Court recognized that the case raised similar concerns to those raised by s. 12 because of the risks attendant upon miscarriages of justice and individual suffering. Not only had Canada abolished capital punishment, but it had also supported international initiatives to restrict or do away with it. The Court admitted, as had the majority in Kindler, that the "evidence does not establish an international law norm against the death penalty, or against extradition to face the death penalty. It does show, however, significant movement towards acceptance internationally of a principle of fundamental justice that Canada had already adopted internally, namely the abolition of capital punishment."114 This principle, therefore, was one in motion or flux, going beyond what it previously was in Kindler and possibly moving towards a stricter if not absolutely prohibitionist norm. The Court did not dispute the very serious interests of Canada in extraditing fugitives. However, as Lamer C.J.C. had argued in dissent in Kindler, those interests were proportionately served by extradition subject to assurances that the death penalty would not be imposed. Although none of these factors alone were conclusive, the Court believed that "taken together they tilt the s. 7 balance against extradition without assurances." 115 The Supreme Court, however, recognized an exception to the rule against extradition without assurances, in a way that presaged the Suresh exception to deportation to torture. Although limitations on s. 7 rights could only rarely be justified under s .1, the Court did not "foreclose the possibility that there may be situations where the Minister's objectives are so pressing, and where there is no other way to achieve those objectives other than through extradition without assurances, that a violation might be justified." "116 Although the facts of Burns did not permit such an exception in that case, there was a future possibility of one.

This exception makes Burns the precursor for the decision in Suresh. ${ }^{117}$ The members of the Court in Suresh were the same as in Burns with the exception that Lamer C.J.C. had stepped down, with his absence filled by Arbour J. and the Chief Justiceship taken by McLachlin. Accordingly, the unanimous decision in Suresh was little surprise, considerably

2001: Liberty vs. Security before the Supreme Court of Canada” (2006) 18 International Journal of Refugee Law 313 at 321-22, 328-29, the change in judicial opinion from Kindler to Burns represented a "jurisprudence of values" rather than a "formalistic approach." With Suresh, they countered, the Supreme Court would swing back towards a formalistic approach in light of post-9/11 security concerns. Since Suresh, the Court has reaffirmed that international law has an important place in Canadian law, only further encouraging this kind of dialogic, constitutional reasoning. See $R$. v. Hape, 2007 SCC 26, [2007] 2 S.C.R. 292 [Hape] (customary international law applies in Canada, absent express conflicting legislation); Canada (Minister of Justice) v. Khadr, 2008 SCC 28, [2008] 2 S.C.R. 125 [Khadr] (the Charter applies extraterritorially where Canadian officials participate in a process that violates Canada's obligations under international law). See Part III.C, below.

Burns, supra note 28 at para. 84.

Ibid. at para. 89.

Ibid. at para. 131.

Ibid. at para. 133. The Court noted that "[t]he Minister must show that the refusal to ask for assurances serves a pressing and substantial purpose; that the refusal is likely to achieve that purpose and does not go further than necessary; and that the effect of unconditional extradition does not outweigh the importance of the objective" (at para. 134).

117 "The Court's judgment in Suresh has many parallels with its judgment in Burns" and it “articulated a general rule that was remarkably similar to Burns: the Constitution would generally prohibit deportation to face torture but might not in undefined exceptional circumstances": Roach, "Dialogues about Rights," supra note 13 at $568,569-70$. 
narrowing the previous ministerial discretion to deport individuals where a torture risk existed. The Court saw

\begin{abstract}
no reason that the principle enunciated in Burns should not apply with equal force here [in Suresh]. In Burns, nothing in our s. 7 analysis turned on the fact that the case arose in the context of extradition rather than refoulement. Rather, the governing principle was a general one — namely, that the guarantee of fundamental justice applies even to deprivations of life, liberty or security effected by actors other than our government, if there is a sufficient causal connection between our government's participation and the deprivation ultimately effected. $^{118}$
\end{abstract}

Nevertheless, the Court in Suresh, as in Burns, still permitted a return to treatment that would shock the conscience. ${ }^{119}$ According to the Court, then, deportation to face either capital punishment or a risk of torture could exceptionally be a proportionate response in light of pressing and substantial public interests.

Burns showed just how the s. 7 balancing test could lead to different results as legal principles, social values, and the relative interests of the individual and the state changed over time. Applying the same analytical framework as it had in Kindler, the Court in Burns found that, within a decade, fundamental justice had transformed from permitting extradition without assurances against the death penalty to requiring them in all but exceptional cases. The implication for reassessment of the Suresh decision, based as it is upon Burns, is that a court can, at any time, re-examine the issue of refoulement and, as a product of $\mathrm{s}$. 7 balancing, determine that the Court in Suresh (1) did no more than leave open the issue of exceptional return to torture for later consideration, (2) simply got the balance wrong and should have gone a step further to forbid return to torture under any and all circumstances, or (3) perhaps balanced the factors reasonably at the time, but that the relevant legal principles and public attitudes have since changed so that return to torture would now violate s. 7 and be per se a disproportionate response unjustifiable under s. 1 . Whichever critical approach to Suresh one adopts, the result is the same: a re-evaluation of the international and domestic factors considered in that case, alongside subsequent developments, indicates that a return to torture will so shock the conscience of Canadians that it will always be an unjustifiable violation of fundamental justice under ss. 7 and 1.

\title{
III. The Non-REFOUlement PRINCIPLE AND “EXTRAORDINARY RENDITION”
}

\section{A. INTERNATIONAL REJECTION OF A NATIONAL SECURITY EXCEPTION}

In assessing the requirements of fundamental justice, the Court in Suresh examined Canadian law and attitudes within a larger international context. ${ }^{120}$ The requirements of fundamental justice were not parochial, but were informed by international norms. The

Suresh, supra note 7 at para. 54 .

119 Ibid. at para. 58 ("Canadian jurisprudence does not suggest that Canada may never deport a person to face treatment elsewhere that would be unconstitutional if imposed by Canada directly, on Canadian soil”). 
provisions of the Immigration Act were also interpreted with regard to international law. ${ }^{121}$ The Court tempered its international inquiries, however: “Our concern is not with Canada's international obligations qua obligations; rather, our concern is with the principles of fundamental justice. We look to international law as evidence of these principles and not as controlling in itself." "22 The Court then undertook a review of the international law on torture and refoulement. It found "three compelling indicia that the prohibition of torture is a peremptory norm.” 123 These were the international conventions prohibiting torture, the fact that no state had legalized or admitted to torture (thereby establishing a pattern of state practice), and a body of international legal authority against torture founded in case law and academic commentaries. ${ }^{124}$ As a peremptory norm, the prohibition of torture allowed no exceptions or derogations and it overrode any conflicting rules of international or domestic law. As for refoulement to a risk of torture, several international sources also prohibited this irrespective of national security considerations and the apparent exception in art. 33(2) of the Refugee Convention. ${ }^{125}$ Drawing on these sources, the Court accepted that s. 7 fundamental justice must be interpreted in line with the international prohibition on torture and the concomitant principle of non-refoulement. ${ }^{126}$

However, despite having regard to international law in Suresh, the Court did not wholly appreciate the full interpretive force of the non-refoulement principle, arising as it did from the peremptory norm against torture and so not permitting the kind of exception that the Court carved out under either s. 7 itself or the s. 1 justification. ${ }^{127}$ The Court recognized that art. 3 of the C.A.T. categorically forbade a return to torture, as well as that General Comment 20 to the I.C.C.P.R. interpreted art. 7 of that convention to forbid refoulement. These instruments overrode art. 33(2) of the Refugee Convention, which on its face appeared to allow a return to torture in national security cases. ${ }^{128}$ The non-refoulement principle enshrined in the C.A.T. thus had a "dominant status" in international law, recognized for example by the U.N.C.A.T. ${ }^{129}$ Furthermore, in the case of Chahal, ${ }^{130}$ the Eur. Ct. H.R. had similarly used international law as an interpretive framework for the prohibition of torture in art. 3 of the E.C.H.R. The Strasbourg Court accordingly adopted the international, absolutist position on non-refoulement to torture. Because the E.C.H.R. art. 3 obligation and the international peremptory norm it represented — was unlimitable and non-derogable, it prohibited deportation to torture under all circumstances, with no exceptions whatsoever.

Ibid. at para. 59, citing Pushpanathan v. Canada (Minister of Citizenship and Immigration), [1998] 1 S.C.R. 982.

Suresh, ibid. at para. 60.

Ibid. at para. 62 .

Ibid. at paras. 62-65.

See supra note 37.

Suresh, supra note 7 at para. 66.

Waters, supra note 74 at 677 [footnote omitted] ("Despite the court's protestations to the contrary, however, human rights treaties appeared to be playing a more important role than as mere 'evidence' of the principles of fundamental justice. Indeed, Canadian domestic law also strongly condemned torture - thus rendering the evidentiary, or persuasive, value of international law redundant, at best”).

See supra note 37.

Suresh, supra note 7 at para. 73; Office of the United Nations High Commissioner for Refugees, "Advisory Opinion on the Extraterritorial Application of Non-Refoulement Obligations Under the 1951 Convention Relating to the Status of Refugees and its 1967 Protocol” [2007] E.H.R.L.R. 483 at 487, 493-94, 495-97, 503 [“Advisory Opinion”].

Supra note 4, discussed in the current Part, below. 
Unfortunately, in Suresh, the Supreme Court ignored the Eur. Ct. H.R.'s Chahal judgment altogether. $^{131}$

Taking these international sources into account, the prohibition on torture and the resultant non-refoulement principle should have factored into the Supreme Court's s. 7 analysis differently and with more weight than did the trend towards the abolition of capital punishment at issue in Burns. ${ }^{132}$ Unlike capital punishment, international law completely prohibits a return to torture and excludes the kind of exception permitted in Burns and Suresh. ${ }^{133}$ From the international perspective, the Court in Suresh incorrectly weighed the relevant factors in carving out a national security exception to the general s. 7 prohibition on return to torture. Moreover, it approached s. 7 in a contradictory way: the Court initially interpreted fundamental justice to reflect the non-refoulement principle, only to effectively conclude that, by permitting an exception, the section actually did not do so. In Suresh then, the Court both misapplied its own balancing test and inconsistently interpreted s. 7 in light of the international law it purported to follow. Although the Court stated that international law did not control its interpretation of the Charter, the judgment did not adequately explain why Canadian values allowed an exceptional departure from the international norm under either s. 7 or s. 1 . These flaws in balancing the competing interests suggest that the Court should have alternatively found that a return to torture would be a violation of s. 7 , always unjustifiable under s. $1^{134}$

Subsequent developments in international law since Suresh only indicate more strongly that a return to torture, under all circumstances, should violate ss. 7 and 1 of the Charter. In 2005, for instance, the U.N.C.A.T. criticized the Supreme Court in Suresh for failing to recognize the absolute nature of the non-refoulement principle enshrined in art. 3 of the C.A.T. ${ }^{135}$ The Committee recommended, among other things, that Canada unconditionally implement art. 3 into domestic law. Later the same year, the U.N.C.A.T. heard an application from Dadar, challenging his deportation to an alleged risk of torture in Iran. ${ }^{136}$ The U.N.C.A.T. reassessed the facts of the case to come to the independent conclusion that substantial grounds did indeed exist for believing Dadar to be at risk of torture. Furthermore,

See Fox-Decent, supra note 18 (criticizing the Federal Court of Appeal in Suresh, C.A., supra note 18, for inappropriately disregarding the Eur. Ct. H.R.'s Chahal decision and underestimating the domestic force of the non-refoulement principle).

Burns, supra note 28 at para. 89, recognized that, despite a global abolitionist trend, capital punishment is not categorically prohibited in international law. An interpretation of s. 7 that allows extradition without assurances in some cases is therefore, unlike refoulement to torture, formally compatible with international law. Compare Soering v. United Kingdom (1989), 161 E.C.H.R. (Ser. A) 3 [Soering]. Because the Suresh Court did not significantly acknowledge that capital punishment differs from torture in that it is indeed still permissible in some circumstances under international law, "[t]he contradiction with Burns cannot be more flagrant": Coutu \& Giroux, supra note 112 at 324. "Suresh, however, is a more disturbing judgment in part because the international law against deportation to torture is more settled and firm than the emerging international law trend against the death penalty that the court identified in Burns": Roach, "Dialogues about Rights," supra note 13 at 569.

"The principle of non-refoulement constitutes the cornerstone of international refugee protection":

"Advisory Opinion," supra note 129 at 484.

The case for interpreting s. 7 consistently with the absolutist principle of non-refoulement in international law, rather than the qualified version in Suresh, seems stronger in light of the decisions in Hape, supra note 112; Khadr, supra note 112.

Conclusions and Recommendations of the Committee against Torture: Canada, U.N.C.A.T., 34th Sess., UN Doc. CAT/C/CR/34/CAN (2005). The Committee also showed concern that Canada's I.R.P.A., supra note 15, s. 115(2), excluded certain individuals from protection from a return to torture (at para. 4(d)). 
the U.N.C.A.T. flatly rejected Canada's argument that, even if that were so, Dadar's danger to the public outweighed his risk of torture if returned. It made clear that "the prohibition enshrined in article 3 of the Convention is an absolute one," 137 a position at odds with the balancing approach of Suresh. Other cases of the U.N.C.A.T. only reaffirm this absolutist position. In a 2005 case against Sweden, ${ }^{138}$ the U.N.C.A.T. found that Sweden had violated art. 3 by returning the applicant to Egypt subject to assurances, where he was subsequently tortured. The U.N.C.A.T. then repeated that "the Convention's protections are absolute, even in the context of national security concerns." ${ }^{139}$ As the C.A.T.'s non-refoulement provision is itself only an expression of a principle stemming from jus cogens, the Suresh exception is clearly at odds with the prevailing rule in international law and contradicts the Supreme Court's own reasoning behind the general s. 7 principle against a return to torture.

The U.N.H.R.C. has also adopted this absolutist position, as seen in the case of Mansour Ahani, challenging his expulsion to Iran based on a fear of torture. ${ }^{140}$ Interestingly, in Canada, Ahani had been a companion case to Suresh. ${ }^{141}$ Although the U.N.H.R.C. was mainly addressing procedural shortcomings in the deportation proceedings and the Canadian failure to stay deportation pursuant to its request for interim protective measures, ${ }^{142}$ it commented on state obligations under the art. 7 prohibition of torture in the I.C.C.P.R. The U.N.H.R.C. extracted a protective principle from art. 7 that placed a duty on states to take positive steps to prevent torture and thereby prohibit refoulement to torture under all circumstances: "The U.N.H.R.C. emphasizes that, as with the right to life, the right to be free from torture requires not only that the State party refrain from torture but take steps of due diligence to avoid a threat to an individual of torture from third parties." ${ }^{433}$ The Committee made further comments that were only thinly-veiled criticisms of the Suresh exception:

\footnotetext{
The Committee does however refer, in conclusion, to the Supreme Court's holding in Suresh that deportation of an individual where a substantial risk of torture had been found to exist was not necessarily precluded in all circumstances. While it has neither been determined by the State party's domestic courts or by the Committee that a substantial risk of torture did exist in the author's case, the Committee expresses no further view on this issue other than to note that the prohibition on torture, including as expressed in article 7 of the Covenant, is an absolute one that is not subject to countervailing considerations. ${ }^{144}$
}

Since Suresh was decided, then, both the U.N.C.A.T. and U.N.H.R.C. have condemned the Canadian Supreme Court's balancing approach in that case and the national security exception to which it led. They have emphasized the absolutist position that both the C.A.T.

Dadar (U.N.C.A.T.), ibid. at para. 8.8.

Agiza v. Sweden, U.N.C.A.T. No. 233/2003, 34th Sess., UN Doc. CAT/C/34/D/233/2003 (2005), (discussed in the current Part, below).

Ibid. at para. 13.8.

Ahani, U.N.H.R.C., supra note 43; for a review of the Ahani case, see Gerald Heckman, "International Decision: Ahani v. Canada" (2005) 99 A.J.I.L. 669; Heckman, "International Human Rights Law Norms," supra note 74.

See supra note 43.

For a lengthy analysis of Ahani, U.N.H.R.C. and interim measures, see Joanna Harrington, "Punting Terrorists, Assassins and Other Undesirables: Canada, the Human Rights Committee and Requests for Interim Measures of Protection” (2003) 48 McGill L.J. 55. For a shorter discussion of why Canadian courts refused to stay proceedings at the request of the U.N.H.R.C., see Roach, "Dialogues about Rights," supra note 13 at 558-64, 574-75.

Ahani, U.N.H.R.C., supra note 43 at para. 10.7.

Ibid. at para. 10.10 [emphasis in original]. 
and the I.C.C.P.R. prohibit refoulement to torture without exception, a protective principle stemming from the peremptory norm against torture in international law. Other jurisdictions have followed this absolutist stance, as seen with the Supreme Court of New Zealand, which explicitly rejected the Suresh exception by interpreting New Zealand law in conformity with international law. ${ }^{145}$ Notably, the Eur. Ct. H.R. has also implicitly rejected the exception in several cases, most recently in Saadi and earlier in Chahal.

In Suresh, the Supreme Court inexplicably failed to take into account the Chahal decision of the Eur. Ct. H.R., a significant European rejection of an exceptional return to torture based upon a Suresh-style balancing test. Indeed, the subsequent case of Saadi, discussion of which opened this article, reaffirmed Chahal and the mandatory nature of the non-refoulement principle in international law, and so categorically rejected a Suresh-style balancing approach as incompatible with the non-refoulement principle. Chahal and Saadi both encapsulate the arguments as to why the Supreme Court of Canada should rethink Suresh and interpret ss.7 and 1 of the Charter to reflect the absolutist principle of non-refoulement to torture. As already explained, in Saadi, the Eur. Ct. H.R. addressed an argument previously made by the U.K. as an intervener in the case of Ramzy. ${ }^{146}$ The U.K. argued that the Eur. Ct. H.R. should reconsider Chahal's absolute prohibition on a return to torture and instead adopt a Sureshstyle balancing test that would allow deportation to a serious risk of torture where exceptional circumstances of national security existed.

The earlier case of Chahal, decided in 1996, raised similar issues to those in Suresh. British authorities had twice arrested Karamjit Singh Chahal (among others) on suspicions of supporting terrorist activities on behalf of Sikh separatists in India, although no charges were ever brought. He had also been tried for assault and affray, although his conviction was later quashed. Based upon his alleged terrorist connections, the Home Secretary then decided in 1990 to deport Chahal to India on national security grounds, first obtaining assurances from India that he would not be abused upon return. Chahal applied for asylum, which was denied, and he also unsuccessfully challenged the deportation order in the British courts. Bringing his case before the Eur. Ct. H.R., Chahal argued that his return to India would violate art. 3 because he faced a risk of torture there. The Eur. Ct. H.R. agreed with the U.K. that Council states had authority to control the entry, residence, and expulsion of aliens, and that the E.C.H.R. did not create a right to asylum. However, it noted that expulsion by a Council state could nevertheless give rise to a E.C.H.R. violation where substantial grounds showed that the individual expelled would face a real risk of prohibited treatment. ${ }^{147}$ In support of this protective principle, the Court cited Soering, ${ }^{148}$ where it had earlier found that extradition to face the "death row phenomenon" in the U.S. would directly lead to treatment contrary to art. 3, while the legitimate state interests behind extradition could be proportionately served by other means. Based on Soering, the Eur. Ct. H.R. in Chahal thus employed a causation test much like that later used by the Supreme Court of Canada in Suresh. The Eur. Ct. H.R. rejected the British argument for a balancing test between the right not to be tortured and state interests in national security. Despite the grave threat presented 
by terrorism, art. 3 "enshrine[d] one of the most fundamental values of democratic society" and so was absolute in its guarantees, irrespective of the individual's conduct. ${ }^{149}$ This protection was

equally absolute in expulsion cases. Thus, whenever substantial grounds have been shown for believing that an individual would face a real risk of being subjected to treatment contrary to Article 3 if removed to another State, the responsibility of the Contracting State to safeguard him or her against such treatment is engaged in the event of expulsion.... In these circumstances, the activities of the individual in question, however undesirable or dangerous, cannot be a material consideration. ${ }^{150}$

Accordingly, the Court assumed the authority to independently assess the facts regarding an alleged risk of torture, undertaking rigorous examination in light of the absolute nature of the non-refoulement principle under art. 3. ${ }^{151}$ The Eur. Ct. H.R. found that a serious risk of torture to Chahal did exist despite the Indian assurances, thereby preventing his return.

In Saadi, the U.K. challenged Chahal's absolutist position. First, it argued that the Chahal approach caused considerable difficulties for Council of Europe states, who could find themselves unable to ever expel individuals posing serious risks, while in many circumstances being unable to prosecute them criminally because of the state's inability to reveal sensitive national security information. The result, then, was that Chahal effectively created a right to asylum for such individuals, a right that the Court in Chahal had admitted was not guaranteed by the E.C.H.R. Furthermore, the U.K. submitted, the drafting history of art. 3 did not evidence such expansive and absolute protection, the C.A.T. and other international jurisprudence might influence but certainly did not control art. 3 interpretation, and art. 3 did not prevent Council of Europe states from taking actions that, through a chain of indirect causation, might only speculatively result in ill-treatment abroad. Finally, the U.K. claimed that the E.C.H.R. framework on the whole balanced individual versus community interests, especially where it created positive obligations, such as that of the state to protect individuals from a risk of torture upon expulsion. Although framed within the terms of the E.C.H.R., the British approach to refoulement was in essence that of Suresh. That is, while art. 3 principles might militate against deportation to torture in most cases, in exceptional instances compelling state interests might override those of the individual and permit return regardless of the torture risk. ${ }^{152}$

The Eur. Ct. H.R. unanimously rejected the U.K.'s proposed balancing test and reaffirmed Chahal. In doing so, it implicitly rejected the Suresh exception in favour of an absolute

Chahal, supra note 4 at para. 79; the Eur. Ct. H.R. has repeatedly emphasized the fundamental nature of art. 3 guarantees to democratic society: see Aksoy v. Turkey (1996), 23 E.H.R.R. 553 at para. 62; Soering, ibid. at para. 88; Vilvarajah, supra note 147 at para. 108; Assenov and Others v. Bulgaria (1998), 96 E.C.H.R. 3264 at para. 93; Selmouni v. France (2000), 29 E.H.R.R. 403 at para. 95; Öcalan v.Turkey (2003), 37 E.H.RR. 10 at para. 179; Saadi, supra note 1 at para. 127.

Chahal, ibid. at para. 80 .

Ibid. at paras. 95-97.

Additionally, as far as assessing the art. 3 risks, the U.K. believed that states should be permitted to rely upon diplomatic assurances from a receiving country that an individual would not be exposed to illtreatment upon return. The implication of such assurances, within the proposed balancing test, seemed to be that courts should defer to governmental assessments of both national security and torture risks a kind of deference that the Supreme Court of Canada extended to ministerial decisions in Suresh under the pragmatic and functional approach. For a summary of the British arguments, see Saadi, supra note 1 at paras. 117-123; Lester \& Beattie, supra note 6; Braswell, supra note 6. 
prohibition on return to torture. It emphasized that art. 3 was an absolute prohibition on torture, and "enshrines one of the fundamental values of democratic societies." 153 No exceptions were permissible for otherwise valid national security concerns. The principle of non-refoulement arose from these "fundamental values" and the peremptory norm in international law, giving it a special status similar to that under the Charter per Suresh. Saadi also made clear that the speculative actions of receiving states were not the controlling issue in a case of refoulement, but rather those of the expelling Council state, which was subject to positive, protective obligations under art. 3. Thus, "[i]n so far as any liability under the Convention is or may be incurred, it is liability incurred by the Contracting State, by reason of its having taken action which has as a direct consequence the exposure of an individual to the risk of proscribed ill-treatment." 154 The decision to expel a foreigner to a risk of torture would not, therefore, be only a remote link in a causative chain, eventually leading to abusive treatment by another country not bound by the E.C.H.R. Rather, the deporting state's role in the chain of causation was itself sufficient to fully engage art. 3 and place upon it the positive obligation to refrain from any actions that would expose an individual currently under its protection to a risk of torture by a third country. This emphasis on causation was like that in Suresh and reoriented responsibility from the receiving, torturing state alone to shared responsibility with the deporting state.

For these reasons, the U.K.’s proposed balancing test was fundamentally “misconceived.” The Court explained:

\footnotetext{
The concepts of "risk" and "dangerousness" in this context do not lend themselves to a balancing test because they are notions that can only be assessed independently of each other. Either the evidence adduced before the Court reveals that there is a substantial risk if the person is sent back or it does not. The prospect that he may pose a serious threat to the community if not returned does not reduce in any way the degree of risk of ill treatment that the person may be subject to on return. For that reason it would be incorrect to require a higher standard of proof, as submitted by the intervener, where the person is considered to represent a serious danger to the community, since assessment of the level of risk is independent of such a test. ${ }^{155}$
}

The Eur. Ct. H.R. reaffirmed Chahal and categorically rejected the notion that the nonrefoulement principle could ever give way to any countervailing concerns of national security — the very notion behind the Suresh exception. ${ }^{156}$

The Eur. Ct. H.R., in Saadi and Chahal, embraced the same, overarching principle of nonrefoulement adopted by the Supreme Court of Canada in Suresh. Where the Eur. Ct. H.R. and the Canadian Supreme Court differed, obviously, was in whether that general principle was absolute or instead subject to some outer limits where public interests could take precedence over the individual right not to be subjected to torture. The Supreme Court, in the face of a clearly absolute international rule against return and ignoring Chahal nevertheless gave in to the temptation to carve out a national security exception to the Charter's incorporation of that principle. The Eur. Ct. H.R., in contrast, interpreted art. 3 of the E.C.H.R. consistently with international law by declaring the protective principle of non-refoulement to be 
absolute. The Eur. Ct. H.R. took this approach in Saadi, while still recognizing the greater threat of terrorism that had arisen since its 1996 decision in Chahal. Saadi therefore signalled that, despite grave and legitimate concerns about terrorism, the Supreme Court of Canada had wrongly concluded in Suresh that a national security exception would be compatible with the international norms and democratic values underlying ss. 7 and 1 of Canada's Charter, the same norms and values that underlie art. 3 of the E.C.H.R.

\section{B. INTERNATIONAL CONDEMNATION OF "EXTRAORDINARY RENDITION”}

In addition to international law and the European position on non-refoulement, international and domestic controversies about extraordinary rendition demonstrate just why the protective principle of non-refoulement is a mandatory concomitant to the peremptory norm against torture. Stories of rendition prove the horrors that can result from a violation of the non-refoulement principle and are relevant to Canadian law for three reasons. First, international criticisms of rendition only further illustrate that the return to torture is absolutely prohibited under international law. Second, rendition shows that the principle of non-refoulement must be absolutely respected as an outgrowth of jus cogens, so that countries cannot unscrupulously avoid their obligation not to inflict torture directly by "shopping out" or "out-sourcing" the dirty work to other willing countries. Third, condemnations from within Canada of rendition (and the few known, unfortunate instances of Canadian complicity with it) suggest that the Canadian public now condemns the return to torture far more strongly than the Supreme Court appreciated at the time of Suresh. The tragic case of Maher Arar, for example, shows how returning someone to torture, or being complicit in rendition practices, can lead to the torment of innocent individuals and shatter their lives. International and domestic outrage over rendition supports the view that returning an individual to a serious risk of torture would so shock the Canadian conscience that it will always be a violation of fundamental justice, unjustifiable under s. 1 .

Over the last several years, there have been serious accusations of torture and other inhuman and degrading treatment of the detainees held by the U.S. at the Guantanamo Bay Naval Base in Cuba. ${ }^{157}$ In September 2004, the then United Nations Special Rapporteur on Torture, Theo van Boven, issued an interim report criticizing the Guantanamo detentions and the policy of returning individuals to a risk of torture. In doing so, he emphasized the principle of non-refoulement, even in the fight against terrorism:

27. With respect to the principle of non-refoulement, it is the essential responsibility of States to prevent acts of torture and other forms of ill-treatment being committed, not only against persons within any territory under their own jurisdiction, as spelled out in article 2, paragraph 1, of the Convention, but also to prevent such acts by not bringing persons under the control of other States if there are substantial grounds for believing that they would be in danger of being subjected to torture.

See Part III.C, below. For lengthy, critical reviews of extraordinary rendition from the American perspective, see Leila Nadya Sadat, "Extraordinary Rendition, Torture, and Other Nightmares from the War on Terror" (2007) 75 Geo. Wash. L. Rev. 1200; David Weissbrodt \& Amy Bergquist, "Extraordinary Rendition: A Human Rights Analysis" (2006) 19 Harv. Hum. Rts. J. 123; The International Committee of the Red Cross has itself made such findings: Neil A. Lewis, "Red Cross Finds Detainee Abuse in Guantánamo” New York Times (30 November 2004), online: New York Times <http://www. nytimes.com/2004/11/30/politics/30gitmo>. 
28. The principle of non-refoulement is an inherent part of the overall absolute and imperative nature of the prohibition of torture and other forms of ill-treatment. ${ }^{158}$

In support of this position, the Special Rapporteur cited the Chahal case, ${ }^{159}$ as well as the decision of the International Criminal Tribunal for the Former Yugoslavia in Prosecutor v. Anto Furundzija. ${ }^{160}$ His successor, Manfred Nowak, followed up this report soon after with criticisms regarding American obstructions of investigations into conditions at Guantanamo Bay. ${ }^{161}$

In 2006, the UN issued two blistering reports on American practices amounting to torture. In February of that year, the United Nations Commission on Human Rights (U.N.C.H.R.) issued a report specifically on Guantanamo Bay. ${ }^{162}$ It detailed how those detentions violated both international human rights and humanitarian law in several ways, including violating the prohibition of torture, as well as the concomitant principle of non-refoulement:

The prohibition of torture provided by the relevant international standards, in particular the Convention against Torture, also encompasses the principle of non-refoulement (art. 3), the obligation to investigate alleged violations promptly and bring perpetrators to justice, the prohibition of incommunicado detention, and the prohibition of the use of evidence obtained under torture in legal proceedings. ${ }^{163}$

The U.N.C.H.R. detailed allegations of treatment of detainees that would constitute torture or other inhuman or degrading treatment or punishment, as well as expressed concern about the transportation, or "rendition," of individuals to receiving states where there was a risk of abuse. ${ }^{164}$ Accordingly, the U.N.C.H.R. concluded that "[t]he practice of rendition of persons to countries where there is a substantial risk of torture ... amounts to a violation of the principle of non-refoulement and is contrary to article 3 of the Convention against Torture and article 7 of ICCPR.”165 It called upon the U.S. to end the practice of rendition. ${ }^{166}$ The U.N.C.A.T. responded to the international condemnations of American practices in July 2006 when it issued its country report on the U.S. ${ }^{167}$ The U.N.C.A.T. roundly condemned the treatment of detainees in the war against terror. Among other things, it denounced suspected secret detention facilities abroad, “enforced disappearances” of terrorist suspects, and their

Commission on Human Rights, Report of the Special Rapporteur on Torture and other Cruel, Inhuman or Degrading Treatment or Punishment, GA Res 59/324, UN GAOR, 59th Sess., UN Doc. A/59/324 (2004) at paras. 27-28.

Chahal, supra note 4 at para. 80.

IT-95-17/1-T, Trial Judgment (10 December 1998) at para. 148 (International Criminal Tribunal for the Former Yugoslavia, Trial Chamber), online: ICTY < http://www.icty.org/x/cases/furundzija/tjug/en/furtj981210e.pdf $>$.

Commission on Human Rights, Report of the Special Rapporteur on the question of torture, Manfred Nowak, UN ESCOR, 62d Sess., UN Doc. E/CN.4/2006/6 (2005).

Commission on Human Rights, Situation of detainees at Guantánamo Bay UN ESCOR, 62d Sess., UN Doc. E/CN.4/2006/120 (2006).

Ibid. at para. 44.

Ibid. at paras. 49-55.

Ibid. at para. 89.

Ibid. at para. 97.

Committee against Torture, Consideration of Reports Submitted by States Parties under Article 19 of the Convention: Conclusions and recommendations of the Committee against Torture - United States of America, 36th Sess., UN Doc. CAT/C/USA/CO/2 (2006). 
calculated rendition to countries where they faced a serious risk of torture. ${ }^{168}$ In that same year, and in response to concerns about rendition, the UN General Assembly urged states not to practice refoulement where there was a risk of torture. ${ }^{169}$

Criticisms of rendition were forthcoming from other international bodies as well. Beginning in late 2005, the Council of Europe extensively investigated allegations of extraordinary rendition by the U.S. and complicity by Council states. In March 2006, the European Commission for Democracy through Law (Venice Commission) issued a lengthy legal opinion on rendition. ${ }^{170}$ In it, the Venice Commission made clear that "[t]he international condemnation of torture has a clear impact on extradition and deportation."171 Under art. 3 of the E.C.H.R., “[a state's] liability may have been incurred ... by reason of its having taken action which has as a direct consequence the exposure of an individual to illtreatment prohibited by Article 3 ECHR." ${ }^{172}$ While the Venice Commission noted that Council state obligations arose directly from art. 3 of the E.C.H.R., it also stated that the prohibition against torture was a peremptory norm under international law and a fundamental right defined under several other international instruments. ${ }^{173}$ Furthermore, the concept of state jurisdiction under art. 3 of the E.C.H.R. was a broad one, comparable to that under the I.C.C.P.R. ${ }^{174}$ Accordingly, the non-refoulement principle under the E.C.H.R. was based on international law and meant that states had a positive duty to protect individuals from torture abroad by third countries. ${ }^{175}$ Based upon this legal opinion and his factual findings, the Rapporteur for the Committee on Legal Affairs and Human Rights, Swiss Senator Dick Marty, subsequently issued a report roundly condemning extraordinary rendition and those states involved in it:

5. Thus, across the world, the United States has progressively woven a clandestine "spider's web" of disappearances, secret detentions and unlawful inter-state transfers, often encompassing countries notorious for their use of torture.

6. The "spider's web" has been spun out with the collaboration or tolerance of many countries, including several Council of Europe member States. This co-operation, which took place in secret and without any democratic legitimacy, has spawned a system that is utterly incompatible with the fundamental principles of the Council of Europe. ${ }^{176}$

Ibid. at paras. 17-18, 20.

Torture and Other Cruel, Inhuman or Degrading Treatment or Punishment, GA Res. 60/148, UN GAOR, 60th Sess., UN Doc. A/RES/60/148 (2006) at para. 8.

Council of Europe, European Commission for Democracy Through Law (Venice Commission), 66th Sess., Opinion no. 363/2005, Opinion on the International Legal Obligations of Council Member States in Respect of Secret Detention Facilities and Inter-State Transport of Prisoners, Opinion 363/2005 (2006), online: Council of Europe Venice Commission <http://www.venice.coe.int/docs/ 2006/CDL$\mathrm{AD}(2006) 009-\mathrm{e} . \mathrm{asp}>$ ["Venice Commission Report”].

Ibid. at para. 67, citing C.A.T., supra note 26, art. 3.

Venice Commission Report, ibid. at para. 69.

Ibid. at paras. 43-44, 47-48, 54-61.

Ibid. at paras. 65-66.

International Covenant on Economic, Social and Cultural Rights, International Covenant on Civil and Political Rights and Optional Protocol to the International Covenant on Civil and Political Rights, GA Res. 2200(XXI)(A), UN GAOR, 21st Sess., Supp. No. 16, UN Doc. A/6316 (1966) 49.

Council of Europe, P.A., Alleged Secret Detentions and Unlawful Inter-State Transfers involving Council of Europe Member States, Committee on Legal Affairs and Human Rights Doc. 10957 (2006) at paras. 5-6. 
Marty's report detailed the extent of the global network of rendition, documented specific individual cases, and accused Council states of varying degrees of complicity in a practice leading to severe human rights abuses, including naming Poland and Romania as hosts of secret American detention facilities where prisoner abuses allegedly occurred.

The above instances are only among the most high-profile examples of the international criticisms against torture and rendition in the war against terrorism. The Marty report reveals the hypocrisy of many countries that otherwise profess to uphold high human rights standards. ${ }^{177}$ It also shows that those same countries feel the need to hide their roles in a complex, secret web of kidnappings, extrajudicial detentions, and torture. ${ }^{178}$ The overwhelming public and official reactions against rendition, combined with the common legal stance of international organizations, only give more weight to the position that sending an individual to be tortured in another country is absolutely incompatible with international law and democratic values, notwithstanding legitimate and weighty national security considerations.

\section{RENDITION AND THE “CANADIAN CONSCIENCE”}

In June 2007, Marty issued a follow-up report for the Council of Europe, confirming allegations of rendition and condemning international complicity in the practice. Named accomplices included Canada. Marty, however, commended Canada for owning up to its responsibility in the American rendition of Canadian citizen Arar to torture in Syria. ${ }^{179}$ That Canada should be accused of both complicity and repentance in extraordinary rendition makes two important points. First, like other governments, the Government of Canada can be tempted to abuse human rights out of an otherwise legitimate concern for national security; temptation, fear, and a false sense of necessity are at the roots of the Suresh exception. Second, when realizing what abuses the Canadian government helped to perpetrate by co-operating with rendition, Canadians were shocked. The resultant public and official response was such to suggest that, in the future, to return an individual to a risk of torture would so shock the conscience that, in contrast to the view of the Supreme Court in Suresh, it could never under any circumstances be justified under the Charter.

Controversy over Canada's involvement in rendition began in late January and early February 2002, when the government confirmed that Canadian forces in Afghanistan had captured prisoners, but then surrendered them into American custody. ${ }^{180}$ Although the Guantanamo Bay detention complex was only just beginning to come into operation, President George W. Bush had already declared that Taliban and Al Qaeda prisoners were to be denied prisoner of war

For a brief analysis of how and why states with otherwise good human rights records might become involved in rendition practices, see Naureen Shah, "Knocking on the Torturer's Door: Confronting International Complicity in the U.S. Rendition Program” (2007) 38 Colum. H.R.L. Rev. 581 at 592-97. The Supreme Court of Canada in Suresh, supra note 7 at para. 63, drew attention to a state practice of condemning torture, even where some states might secretly perpetrate, tolerate, or be complicit in prohibited treatment. Such hypocrisy, however, was itself evidence to the Court of the normative force of the torture ban, as no state would officially and openly sanction such abuse, instead feeling the need to conceal and deny it.

Council of Europe, P.A., Secret Detentions and Illegal Transfers of Detainees involving Council of Europe Member States: Second Report, Committee on Legal Affairs and Human Rights Doc. 11302 (2007) at paras. 1, 325-34.

180 "Eggleton confirms JTF2 had taken prisoners in Afghanistan" CBC News (30 January 2002), online: CBC <http://www.cbc.ca/canada/story/2002/01/29/jtf2020129.html>. 
status under the Geneva Convention Relative to the Treatment of Prisoners of War ${ }^{181}$ and subject to trial by special military tribunals. ${ }^{182}$ Furthermore, there were already early accusations that the U.S. military was abusing prisoners taken in Afghanistan. ${ }^{183}$ The Canadian government belatedly halted the transfer of Afghanistan prisoners to the U.S. because of increasing allegations of American abuses, instead handing them over to Afghan national authorities. However, in early 2007 charges would surface that the Canadian military had been handing over captives despite knowing there to be a serious risk of torture in Afghan prisons. Although Canada temporarily ceased transfers, it controversially resumed them in early 2008 subject to new procedures intended to decrease risks. ${ }^{184}$

Amnesty International and the British Columbia Civil Liberties Association challenged such prisoner transfers in court. In Amnesty International Canada v. Chief of the Defence Staff, ${ }^{185}$ the Federal Court decided that the Charter did not apply to military operations on foreign territory, even if torture was a risk. The Federal Court of Appeal affirmed that decision, while the Supreme Court refused to hear an appeal. ${ }^{186}$ While the Court of Appeal has therefore found against a blanket extraterritorial application of the Charter, its ruling does not change the causation analysis that the Supreme Court used in Suresh in finding a general s. 7 prohibition against torture. That is, where the Charter does apply to Canadian actions taken in Canada having a sufficient causal connection to actions abroad, the protective principle of the torture prohibition will restrain those actions leading to the possibility of torture by foreign parties.

Furthermore, the very question of extraterritorial application of the Charter remains an unsettled one after the Supreme Court recently decided in Khadr ${ }^{187}$ that the Charter does apply extraterritorially in some circumstances. Canadian officials interviewed Omar Khadr, a teenage Canadian citizen, for intelligence information while he was imprisoned by the U.S. at Guantanamo Bay as an underage, unlawful combatant. Canada shared the result of Khadr's interrogations with the U.S., thereby providing evidence for terrorism-related charges to be tried by an American military commission. Khadr argued that s. 7 of the Charter required the Canadian government to disclose to him information it had gathered from his interviews at Guantanamo for use in his defence in the U.S. The Supreme Court found that principles of international law and the comity of nations, which otherwise limit operation of the Charter abroad, do not apply when Canadian officials participate in processes that violate Canada's obligations under international law. In support of this proposition, the Court cited its earlier decision in Hape, per LeBel J., that the Charter could apply extraterritorially where actions of

12 August 1949, 75 U.N.T.S. 136 (entered into force 21 October 1950).

See U.S. White House, "Fact Sheet: Status of Detainees at Guantanamo" (7 February 2002), online: The White House <www.whitehouse.gov/news/releases/2002/02/20020207-13.html>; U.S. White House, "Military Order: Detention, Treatment, and Trial of Certain Non-Citizens in the War Against Terrorism" (13 November 2001), online: The White House <http://www.whitehouse.gov/news/releases/2001/11/ 20011113-27.html>.

"Canadian troops in Afghanistan will respect international law: Eggleton” CBC News (29 January 2002), online: CBC <http://www.cbc.ca/canada/story/2002/01/28/debate020128.html>.

“The controversy over detainees: Are prisoners of war Canada's responsibility?” CBC News (27 April 2007), online: CBC <http://www.cbc.ca/news/background/afghanistan/detainees.html>; "Canadian Military Resumes Transfer of Detainees” CBC News (29 February 2008), online: CBC <http://www. cbc.ca/world/story/2008/02/29/detainees-afghanistan.html>.

2008 FC 336, [2008] 4 F.C.R. 546.

Amnesty International Canada v. Canada (Canadian Forces), 2008 FCA 401, 383 N.R. 268; "Supreme Court of Canada won't hear Afghan detainee case” CBC News (21 May 2009), online: CBC <http:// www.cbc.ca/canada/story/2009/05/21/court-afghan-prisoner-abuse021.html>. Khadr, supra note 112. 
Canadian authorities might lead to serious violations of fundamental human rights. ${ }^{188}$ The Court in Khadr explained, in the event of such actions, "the Charter applies to the extent of that participation." 189 In circumstances where it did apply, s. 7 fundamental justice was accordingly to be interpreted according to Canada's human rights obligations. ${ }^{190}$ Since the U.S. Supreme Court itself had found that various aspects of the Guantanamo detention and military commission regime violated U.S. and international law, Canadian participation in those processes attracted Charter coverage. ${ }^{191}$ Consequently, s. 7 required disclosure of all interview records and any other information passed to the U.S. as a direct consequence of those interviews. Together, Hape and Khadr seem to establish a case-specific "severity threshold" for evaluating just what Canadian actions trigger Charter protections outside of Canada. This threshold is easily passed by actions leading to or benefiting from an individual's torture by a third country.

Canadian actions, like those exemplified in the Afghan conflict and the above legal cases, illustrate just how some actions taken in the interests of national security can all too easily lead to torture at the hands of other countries and, in so doing, violate Canadian obligations under international law. First, the Khadr case showed how government officials might exploit abusive treatment meted out by other countries in order to gain intelligence information otherwise impermissible under domestic law, thus "outsourcing” torture. Second, all of the above cases concern highly criticized and high-profile actions of the Canadian government, at odds with Canada's humanitarian values and positive world image. For example, Gen. Romeo Dallaire has charged that "[t]he international community notices all of Canada's glaring missteps on the world stage and carefully compares our words to our actions. If we continue to allow discrepancies between the two, we will quickly become known as ‘the ugly Canadian' — hypocritical in the international community and uncaring at home." ${ }^{92}$ Canada's unsavoury complicity with the American rendition program and the possibility of the expulsion of foreigners to a serious risk of torture elsewhere, as contemplated by the Suresh exception, therefore undermine the very values that national security measures are meant to protect. Complicity also confirms that the absolute principle of non-refoulement is necessary to give full force to the peremptory norm against torture and to prevent conspiracies among nations to avoid it, and in so doing promote s. 7 fundamental justice.

An especially stark example of Canadian involvement in refoulement and rendition drives these points home. The dangers that these practices pose both to the effective enforcement of the peremptory norm against torture and basic Canadian values become glaringly apparent in the case of Arar. The basic facts of the Arar incident are well-known, but deserve brief mention. In September 2002, Arar, a dual Canadian and Syrian national, was returning to Canada from Tunisia via Zurich and New York (using his Canadian passport), when he was detained by U.S. authorities during the New York stopover. The Americans held Arar for some time before informing him that, because of alleged involvement in terrorist activities, he was to be removed — not back to his home in Canada, but to Syria. Despite his Canadian citizenship and his

Ibid. at paras. 17-18, citing Hape, supra note 112 at paras. 51, 52, 56, 101.

Khadr, ibid. at para. 19.

Ibid. at para. 29, citing Suresh, supra note 7; Burns, supra note 28.

Khadr, ibid. at paras. 21-24. See Rasul v. Bush, 542 U.S. 466 (2004); Hamdan v. Rumsfeld, 548 U.S. 557 (2006).

Romeo Dallaire, "Bring Omar Khadr home” National Post (31 March 2008), online: National Post <http://www.nationalpost.com/story.html?id=411288>; Gen. Dallaire is a Senator and the former Commander of the UN Assistance Mission to Rwanda at the time of the genocide there. 
protestations, Arar was indeed returned to Syria. The American decision to detain and deport Arar was based, at least partly, on intelligence information obtained from Canadian authorities that linked Arar to terrorism. Upon his arrival in Syria, Syrian authorities imprisoned and tortured Arar for several months, all the while interrogating him about alleged connections to Al Qaeda. Canadian officials eventually secured his release and he returned to Montréal after a year in Syrian custody. ${ }^{193}$

The Arar case seems a fairly straightforward instance of rendition, and is a clear example of why respect for the non-refoulement principle is necessary to give full effect to its legal source, the peremptory norm against torture. The Americans clearly chose to deport Arar to a country notorious for its use of torture with the apparent hope that officials there could do what American (or Canadian) authorities clearly could not legally do themselves in North America: physically and brutally coerce Arar into providing incriminating evidence about him or his associates. By sending him to Syria - fully aware of its abysmal human rights record and knowing (or, even more sinisterly, intending) that he would be tortured and abusively interrogated by the Syrians because of his alleged terrorist activities - the American government was attempting to evade its obligation not to torture under both domestic and international law. National security justifications, no matter how exceptional, cannot ever justify a return to a risk of torture, as the kind of "outsourcing" involved in the Arar case grossly undermines the absolute prohibition against torture. In this regard, the Arar case merits strong criticism and raises the same concerns as does the general practice of extraordinary rendition.

Concerns about Canadian complicity became the subject of the official Commission of Inquiry in the Arar affair. ${ }^{194}$ The main thrust of the Commission's findings was that, when the Americans informed Canadian authorities that they intended to detain Arar for questioning upon his arrival in New York, those authorities shared intelligence and law enforcement files relating to Canadian suspicions about Arar's association with suspected terrorists. This information about Arar's terrorist links was not only faulty (resulting in his complete exoneration by the Commission), it also misrepresented and exaggerated the extent and severity of those suspected links. This information was, it appears, a significant basis for the American decision to remove Arar to Syria. Certainly, Canadian officials had done little more than share information on Arar with the Americans. Moreover, they also seem to have had no advance knowledge that Arar would be sent to Syria, rather than back to Switzerland or to Canada. Added to this, the Government worked over a course of time to secure Arar's eventual release by the Syrians. Nevertheless, even this low level of complicity or reckless trust in the American authorities caused a public uproar, eventually leading to the official Commission of Inquiry, the exoneration of Arar with significant financial compensation, and an official apology by the Prime Minister to Arar on behalf of Canada. ${ }^{195}$

As judged from the Arar incident, the Supreme Court had certainly been correct in Suresh when it found that return to torture shocks the Canadian conscience. In allowing for a national

A voluminous and exhaustive recounting of the facts of the Arar case is to be found in Canada, Commission of Inquiry into the Actions of Canadian Officials in Relation to Maher Arar, Report of Professor Stephen J. Toope Fact Finder, online: Library and Archives Canada <http://epe.lac-bac.gc. ca/100/206/301/pco-bcp/commissions/maher_arar/07-09-13/www.ararcommission.ca/eng/17.htm>.

195 "Harper’s Apology 'Means the World': Arar” CBC News (26 January 2007), online: CBC <http:// www.cbc.ca/canada/story/2007/01/26/harper-apology.html>. 
security exception at that time, however, the Court failed to appreciate that even the extraordinary violation of the non-refoulement principle would make Canada an accomplice to criminal acts of torture by others. Recognizing a new Canadian sensitivity after the Arar affair, the Supreme Court later noted in Charkaoui that while the national security context may indeed necessitate occasional, extraordinary government intrusions on individual liberty, "it is a context that may have important, indeed chilling, consequences for the detainee.”196 In light of such recent experiences, then, neither judges nor politicians can believably claim ignorance of, nor innocence from, their parts in such foreseeable human tragedies. Like Lady MacBeth, Canada cannot wash from its hands the invisible blood spilled by another and it bears responsibility for those foreseeable, chilling consequences. In permitting return to torture under the Suresh exception, the Canadian judiciary would be just as culpable as the Government in ordering it. At the first opportunity to reconsider Suresh, a court should reflect back on the post-September 11 experiences with refoulement and rendition, as well as look forward to an uncertain future. Taking the long view, it should see that to send even the most wicked individual to face beatings, starvation, electric shocks, rape, simulated execution, or any other barbaric abuse by another country will shock the Canadian conscience not only in most cases, but in every possible case. ${ }^{197}$ The imagination of Canada's public officials is not so feeble that they cannot fashion other humane, strong, effective, and proportionate measures to protect Canadians, consistent with their democratic and humanitarian values. Fundamental justice demands, and a free and democratic society will justify, no less.

\section{CONCLUSION}

In response to the threat of international terrorism, Canada and other states have felt increasingly compelled to take extraordinary legal measures in protecting public safety and national security. This security pressure has resulted in special anti-terrorism laws in several jurisdictions, and has spurred Canada and other nations to take tougher stances on immigration policy and enforcement. Of course, the Canadian government has long had the power to expel immigrants determined to pose a national security risk. However, in recent years, heightened security concerns and transnational efforts to counter terrorism have focused attention on immigration in Canada and elsewhere. While states do have legitimate interests in not harbouring foreign criminals or individuals reasonably suspected of terrorist involvement, they nevertheless do not have complete plenary power to remove such persons from their territory. Despite the state's ordinarily broad authority in admitting, refusing, or expelling foreigners, international law draws one very clear line beyond which no state may cross: a state may not return a person to a third country where he faces a serious risk of torture or other inhuman or degrading treatment or punishment. This protective principle of non-refoulement allows no exception for national security, the threat of terrorism notwithstanding.

International bodies, such as the U.N.C.A.T. and U.N.H.R.C., have made very clear the absolute nature of the peremptory norm against torture and its derivative protective principle of non-refoulement. Notably, the Eur. Ct. H.R. has upheld this principle in interpreting the art. 3 prohibition of torture in the E.C.H.R. In the recent case of Saadi, the Court in Strasbourg

196 Charkaoui, supra note 15 at paras. 25-26.

197 As stated in Roach, "Must We Trade," supra note 46 at 2194, “[t]he Suresh exception for deportation to torture is ... morally abhorrent and in violation of international law." 
unanimously and unreservedly reaffirmed its previous decision in Chahal that a Council of Europe state could never return an individual to a serious risk of prohibited treatment. The decision in Saadi was especially significant as it categorically rejected British arguments that the Chahal ruling should be overturned in favour of a balancing test, whereby a Council state could weigh an individual's threat to national security against his right not to be returned to torture. This test could have the result that, in exceptional cases, the state could indeed send a person to torture in a third country. The British argument for a balancing test closely resembled the one earlier adopted by the Supreme Court of Canada in Suresh, leading to an unflattering comparison with Canadian law. While the Suresh Court had indeed found that fundamental justice normally prevents a return to torture, it too engaged in a balancing exercise that left room for an exceptional case of return to torture under either s. 7 or s. 1 of the Charter. The Suresh exception, like the unsuccessful British arguments in Saadi, therefore contravenes the absolutist non-refoulement principle and, even though not yet successfully invoked by the Canadian government, falls short of Canada's human rights obligations.

Upon reflection, the position of such bodies as the U.N.C.A.T. and the lamentable international experiences with extraordinary rendition all show that the Suresh exception not only violates international law, but must now be considered to be inconsistent with the Canadian values at issue in ss. 7 and 1 of the Charter itself. To knowingly return an individual to a serious risk of torture, under any circumstances, is an abhorrent state practice that shocks the conscience of Canadians; this is so not only in most cases, but under all circumstances, including those giving rise to otherwise pressing and substantial national security interests. Refoulement to torture is at all times a violation of fundamental justice, per se disproportionate to the state interests involved. As such, refoulement can never be demonstrably justifiable in a free and democratic society. The Suresh exception, upon reconsideration, must now be seen as incompatible with the Charter and a court should remove this exception at the first possible opportunity in order to remove any doubts at home and to dissuade perverse emulation abroad.

Respect for the principle of non-refoulement, however, does not weaken Canada's ability to take tough anti-terrorism measures. To the contrary, it requires (and indeed is a positive opportunity for) Canada to deal with Suresh's exceptional case in a legitimately strong way that comports with Canadian values and human rights. Parliament and government should use established legal measures or, if necessary, find new, imaginative, but proportionate solutions to Suresh's exceptional case. For example, the Criminal Code ${ }^{198}$ already provides ample grounds to prosecute an individual for various terrorism-related offenses. Another option, proposed by the Government in Bill C-19, ${ }^{199}$ is for Parliament to re-enact special recognizance provisions (such as those originally in s. 83.3 of the Anti-Terrorism Act, ${ }^{200}$ before they lapsed under a sunset clause), tailored to exceptional, individual circumstances. Any alternatives, of course, must have adequate procedural safeguards and, in some cases, should be the subject of regular parliamentary review or further sunset clauses. Otherwise, to fight terrorism by returning people to torture, and thereby undermining jus cogens, is to protect the public safety and national security in a grossly disproportionate way at the expense of the fundamental humanitarian values upon which Canada and other democracies rest. There can be no justification for a return to torture. The necessary rejection of jus cogens internally contradicts the otherwise legitimate state

199 Bill C-19, An Act to amend the Criminal Code (investigative hearing and recognizance with conditions), 2d Sess., 40th Parl., 2009 (1st reading 12 March 2009). 
interest at stake; that being a substantively enriched notion of national security, whereby the state defends core values just as much as it does lives, property, or territory. It is arguable, of course, whether or not expulsion under the Suresh exception would be more or less cumbersome, efficient, or effective in protecting national security than any number of alternative options for detaining or monitoring non-deportable individuals. Nevertheless, these wholly pragmatic concerns cannot override the fundamental human right not to be tortured. In Suresh, however, the Supreme Court suggested that it might indeed be prepared to trade-off Canada's core values and international reputation for temporary and possibly illusory security. It is time that Canadian courts recognize this as a bad bargain and reject the Suresh exception in favour of commitment without exceptions to the principle of non-refoulement. 